\title{
Hanford Reach Fall Chinook Redd Monitoring Report for Calendar Year 2013
}

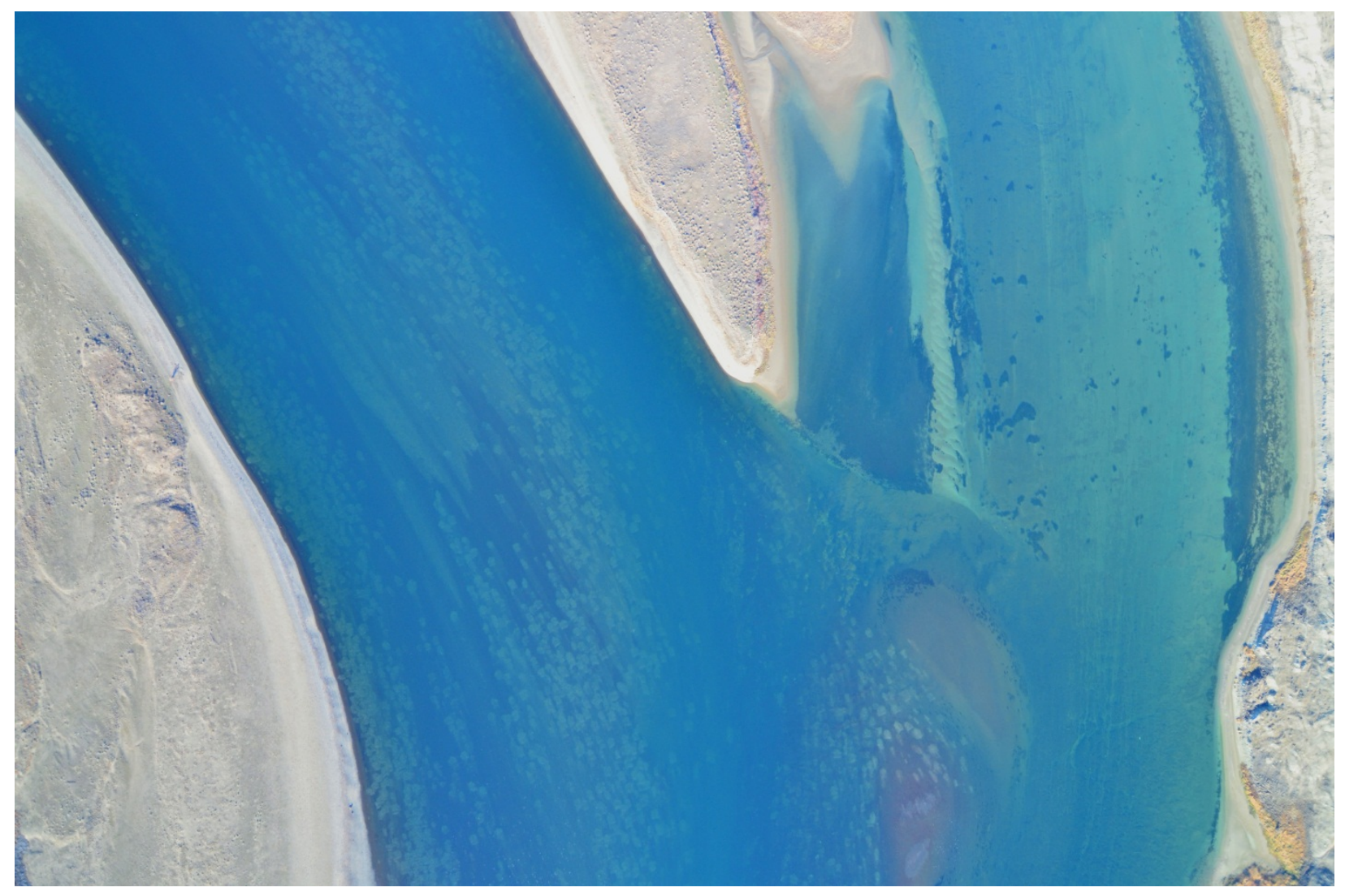

Prepared for the U.S. Department of Energy

Assistant Secretary for Environmental Management

Contractor for the U.S. Department of Energy

under Contract DE-AC06-09RL14728

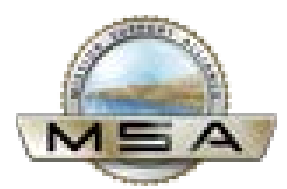

P.O. Box 650

Richland, Washington 99352 
HNF-56707

Revision 0

TRADEMARK DISCLAIMER

Reference herein to any specific commercial product, process, or service by trade name, trademark, manufacturer, or otherwise, does not necessarily constitute or imply its endorsement, recommendation, or favoring by the United States Government or any agency thereof or its contractors or subcontractors.

This report has been reproduced from the best available copy.

Printed in the United States of America

The cover photo is courtesy of Cole Lindsey and John Nugent. 


\section{Hanford Reach Fall Chinook Redd Monitoring Report for Calendar Year 2013}

C. Lindsey and J. Nugent

Mission Support Alliance

Date Published

February 2014

Prepared for the U.S. Department of Energy

Assistant Secretary for Environmental Management

Contractor for the U.S. Department of Energy

under Contract DE-AC06-09RL14728

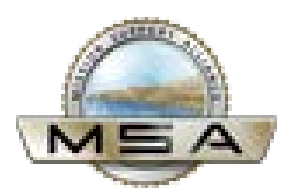

P.O. Box 650

Richland, Washington 99352

APPROVED

By Janis D. Aardal at 3:03 pm, Feb 10, 2014 


\section{Contents}

$1.0 \quad$ INTRODUCTION ...........................................................................................................

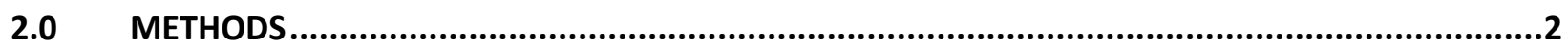

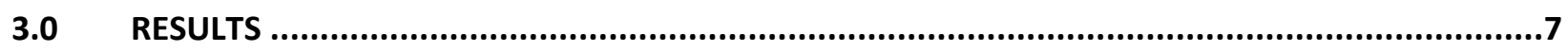

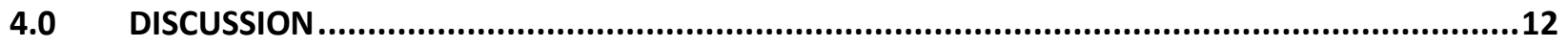

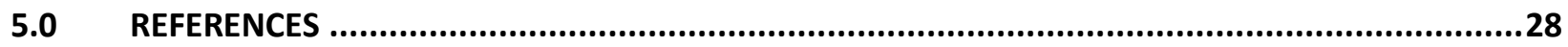

Figures

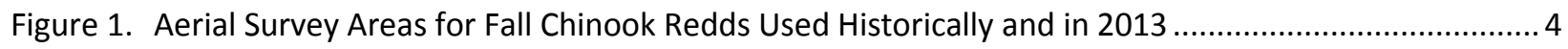

Figure 2. Fall Chinook Survey Sub-areas Adjacent to Groundwater Contamination Plumes. ............................. 5

Figure 3. Digital Camera Mounted Over Airplane Hatch ............................................................................. 7

Figure 4. Georeferenced Aerial Photographs of the Hanford Reach Taken During 2013................................. 9

Figure 5. Three Overlapping Georeferenced Aerial Photographs from 2013................................................ 10

Figure 6. Aerial Photograph Taken in 2013 of Redds Near Island 2 in the Hanford Reach (Image

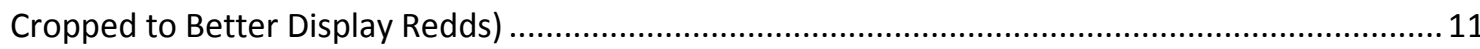

Figure 7. Visual Hanford Reach Fall Chinook Salmon Redd Counts 1948 to 2013 ......................................... 13

Figure 8. Relationship Between Annual Visual Fall Chinook Maximum Redd Count and Estimated

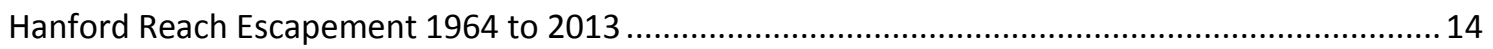

Figure 9. Redd Cluster with High Degree of Superimposition (Image Cropped to Better Display Redds).......... 15

Figure 10. Upper Hanford Reach Digitized Redd Locations for 2013 ......................................................... 17

Figure 11. Middle Hanford Reach Digitized Redd Locations for 2013 ........................................................ 18

Figure 12. Lower Hanford Reach Digitized Redd Locations for 2013......................................................... 19

Figure 13. Upper Hanford Reach Fall Chinook Spawning Areas Pre-2013 and From 2013 ............................. 20

Figure 14. Middle Hanford Reach Fall Chinook Spawning Areas Pre-2013 and From 2013 ............................. 21

Figure 15. Lower Hanford Reach Fall Chinook Spawning Areas Pre-2013 and From 2013 .............................. 22

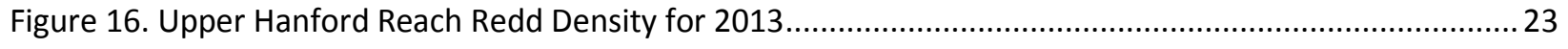

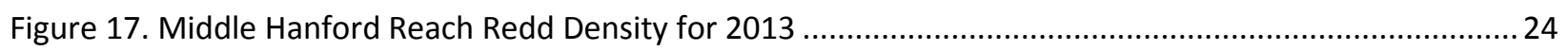

Figure 18. Lower Hanford Reach Redd Density for 2013 ........................................................................... 25

\section{Tables}

Table 1. Summary of Fall Chinook Visual Aerial Redd Counts for the CY2013 Aerial Surveys in the

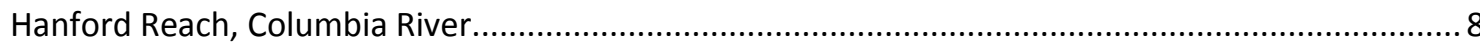

Table 2. Summary of Fall Chinook Visual Aerial Redd Counts for the CY2013 Aerial Surveys by

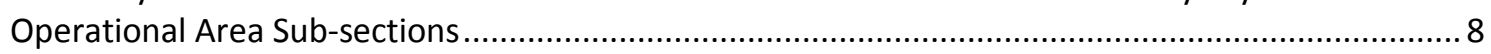

Table 3. Photo Gap Statistics by Area and Corresponding Redd Count Estimates ...........................................2 26

Table 4. Photo Gap Statistics by Sub-Area and Corresponding Redd Count Estimates.....................................27 
HNF-56707

Revision 0

\subsection{Introduction}

The U.S. Department of Energy, Richland Operations Office (DOE-RL) conducts ecological monitoring on the Hanford Site to collect and track data needed to ensure compliance with an array of environmental laws, regulations, and policies governing DOE activities. Ecological monitoring data provide baseline information about the plants, animals, and habitat under DOE-RL stewardship at Hanford required for decision-making under the National Environmental Policy Act (NEPA) and Comprehensive Environmental Response, Compensation, and Liability Act (CERCLA). The Hanford Site Comprehensive Land Use Plan (CLUP, DOE/EIS-0222-F) which is the Environmental Impact Statement for Hanford Site activities, helps ensure that DOE-RL, its contractors, and other entities conducting activities on the Hanford Site are in compliance with NEPA.

The Hanford Site Biological Resources Management Plan (BRMP, DOE/RL 96-32 Rev 1) is identified by the CLUP as the primary implementation control for managing and protecting natural resources on the Hanford Site. According to the CLUP, the BRMP

"provides a mechanism for ensuring compliance with laws protecting biological resources; provides a framework for ensuring that appropriate biological resource goals, objectives, and tools are in place to make DOE an effective steward of the Hanford biological resources; and implements an ecosystem management approach for biological resources on the Site. The BRMP provides a comprehensive direction that specifies DOE biological resource policies, goals, and objectives. "

DOE-RL places priority on monitoring those plant and animal species or habitats with specific regulatory protections or requirements; or that are rare and/or declining (federal or state listed endangered, threatened, or sensitive species); or of significant interest to federal, state, or tribal governments or the public. The BRMP ranks wildlife species and habitats (Levels 0-5), providing a graded approach to monitoring biological resources based on the level of concern for each resource. Fall chinook spawning areas are ranked as Level 5 resources, the highest ranking level in BRMP. According to BRMP, Level 5 resources require a "High" level of status monitoring. As such, fall chinook redds have been monitored annually since 1948.

The population of Chinook salmon (Oncorhynchus tshawytscha) that spawns in the Hanford Reach of the Columbia River is the largest run remaining in the Pacific Northwest and has regional ecological and cultural significance as well as economic importance that extends down the Columbia River and into the Pacific Ocean as far as southeast Alaska (Dauble and Watson 1997). These fall Chinook have been vital in efforts to preserve and restore other depleted Chinook stocks in the Columbia Basin (Anglin et al. 2006). Aerial counts of Chinook salmon redds have been conducted since 1948 at Hanford to provide an index of relative abundance among spawning areas and years (HNF-54808, HNF-52190, MSA 2014). The counts are also used to document the onset of spawning, to locate spawning areas, and to determine intervals of peak spawning activity. These data also allow for planning to avoid impacts, such as disturbance or siltation, to redds from Hanford Site activities. Understanding the location and 
abundance of spawning is a critical part of the management of this important population. The information collected during the surveys, that are the focus of this report, is vitally important for the implementation of the Hanford Reach Fall Chinook Protection Program (USACE 2006).

Chinook salmon, also commonly referred to as king salmon, are the largest of the Pacific salmon (Myers et al. 1998, Netboy 1958). The Columbia River supports three major runs (spring, summer, and fall) of Chinook salmon, generally based upon the season during which the adults re-enter the estuary to begin their upstream migration to spawn. Chinook salmon that spawn in the Hanford Reach of the Columbia River are fall-run fish. Fall Chinook salmon enter freshwater at an advanced stage of maturity, move rapidly to their spawning areas on the mainstem or lower tributaries of the rivers, and spawn within a few days or weeks of freshwater entry (Myers et al. 1998, Fulton 1968, Healey 1991). Adult fall Chinook salmon destined for the Hanford Reach are upriver brights, which enter the Columbia River in late summer and spawn in the fall. Spawning in the Hanford Reach typically begins in mid-October and lasts through November. From 1948 through 1988, the first-observation of spawning ranged from September 28 to October 26 with a median date of October 16 (Dauble and Watson 1990). Females fan out nests or "redds" in suitable gravel substrate and deposit eggs in an egg pocket while males simultaneously extrude milt to fertilize the eggs. Redds are readily identifiable at this time and appear as clean swept gravel patches amidst darker undisturbed substrate that is covered by algae (periphyton). "Redd life" is a term describing the period of time when periphyton growth has not rendered the redd substrate indiscernible from the surroundings. Redd life is typically about six weeks on the Hanford Reach (Dauble and Watson 1990), but redds have been recorded to remain visible for over 16 weeks (

\subsection{Methods}

Aerial surveys of fall Chinook redds were conducted in areas of the Hanford Reach consistent with past survey efforts and the historical database (Figure 1). Eight additional sub-sections (100-B/C, 100-K, $100-\mathrm{N}, 100-\mathrm{D}, 100-\mathrm{H}, 100-\mathrm{F}$, Dunes, and 300 Area) were added, beginning in 2011, to better monitor the abundance and distribution of fall Chinook redds in areas of the Columbia River adjacent to contaminated groundwater plumes of the Hanford Site (Figure 2) (DOE/RL-2011-119). These eight new sub-sections were added to the DOE-RL Public Safety and Resource Protection Program's (PSRP) database. This change to the historical monitoring technique provides additional spatial resolution to the survey information, but the sum of redd counts in the original areas allows newly collected data to be directly comparable to historical records.

The primary physical factors influencing the accuracy of aerial counts include depth of water over redds and water clarity. Wind action, available light, orientation of the river, and direction of the current can also affect redd counts. Accuracy of aerial redd counts also decreases with increasing numbers and density of redds within a large aggregate of redds (Visser et al. 2002). Flights are cancelled if weather conditions are adverse (i.e., wind, fog, or low clouds). Field measurements suggest that the upper depth limit for detecting redds during aerial surveys conducted on the Hanford Reach in 1988 was 3-4 meters (m) [10-13 feet (ft)] (Dauble and Watson 1990). Other studies indicate that fall Chinook 
salmon spawn in water up to $9 \mathrm{~m}$ (30 ft) deep (Swan 1989). Therefore, a proportion of redds located in deeper water may not be detected during aerial surveys (Dauble and Watson 1990). Because it is seldom possible to view all redds from the air, these counts provide a consistent annual index of relative abundance and distribution of fall Chinook spawning in the Hanford Reach of the Columbia River.

Beginning in mid-October, under the terms of the Hanford Reach Fall Chinook Protection Program Agreement, river flows are reduced every Sunday morning (day of lowest power demand) to the Priest Rapids Dam minimum operating discharge of 36,000 cubic feet per second $\left(\mathrm{ft}^{3} / \mathrm{s}\right.$ ) [1,000 cubic meters per second $\left.\left(\mathrm{m}^{3} / \mathrm{s}\right)\right]$. This allows the Agency and Utility Party Monitoring Team to manually survey for redd distribution at Vernita Bar just downstream of Priest Rapids Dam. These drawdowns occur every Sunday morning until the initiation of fall Chinook spawning has been set both above and below the $50,000 \mathrm{ft}^{3} / \mathrm{s}\left(1,416 \mathrm{~m}^{3} / \mathrm{s}\right)$ flow elevations. A final drawdown is conducted on the Sunday prior to Thanksgiving to establish the minimum critical flow needed to protect pre-emergent fall Chinook. Given the previously described limitations, this weekly reduction in river flow affords the best viewing conditions for aerial flights. Aerial flights are therefore scheduled to be conducted concurrent with the Sunday morning drawdowns, when possible. 
HNF-56707

Revision 0

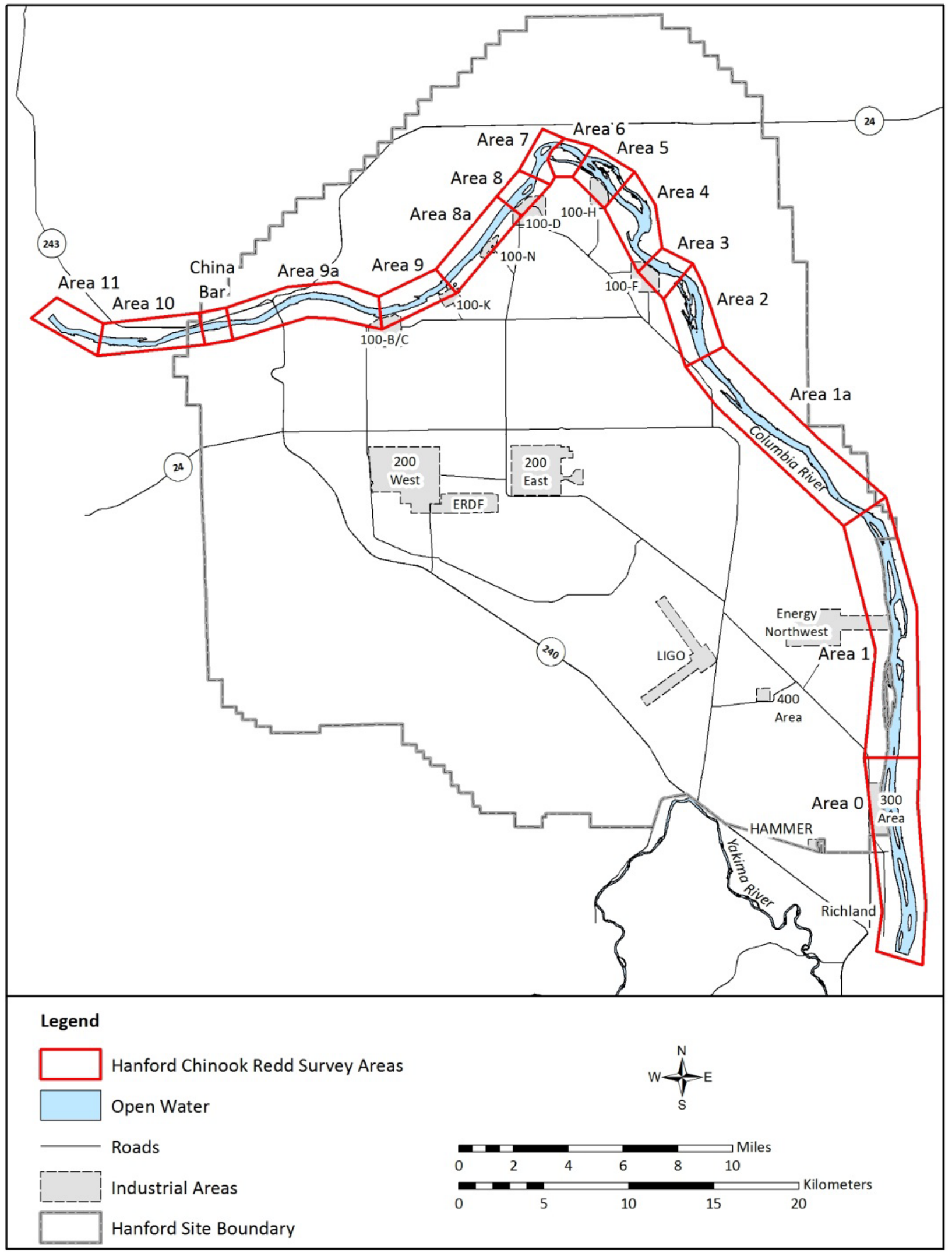

Figure 1. Aerial Survey Areas for Fall Chinook Redds Used Historically and in 2013 
HNF-56707

Revision 0

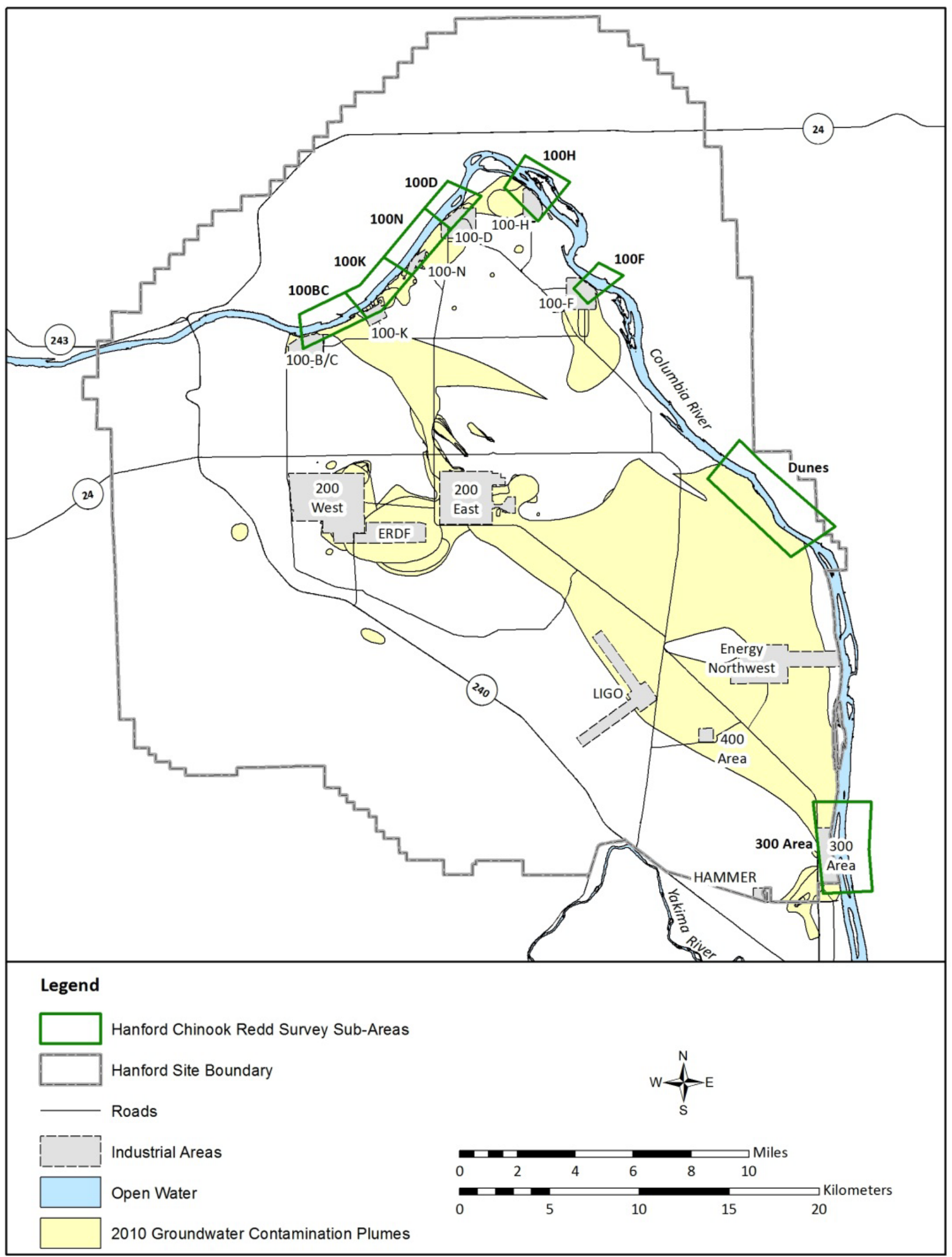

Figure 2. Fall Chinook Survey Sub-areas Adjacent to Groundwater Contamination Plumes. 
Flights are scheduled from mid-October (initiation of spawning) through the third week of November (end of spawning) to encompass the entire fall Chinook spawning period. As indicated above, flights are scheduled on Sundays to maximize low flow viewing conditions. Three to four flights are typically conducted during this period. Early flights (October) are conducted to establish the initiation of spawning. Later flights (November) are conducted during and just after the peak spawning period to establish the maximum redd count for the season by area and for the entire Hanford Reach. Multiple flights are necessary to minimize the effect of poor visibility, or other sources of count variability, that may occur during a single flight. Multiple flights also ensure comparability within the long-term database through consistency with past efforts. As a courtesy, consistent with past practices, aerial redd count information is shared with the Hanford Reach Fall Chinook Protection Program parties to assist in the implementation of protective measures.

Survey flight altitudes range from 244 to $366 \mathrm{~m}$ [800 to $1200 \mathrm{ft}$ ] with air speeds of 120 to 161 kilometers per hour (kph) [75 to 100 miles per hour (mph)]. Widely spaced fall Chinook redds are individually counted while tightly grouped clusters of redds are estimated in groups of 10 or 50 . Heavy spawning areas require multiple aerial passes in order to collect complete counts. Observations begin in Richland at the I-182 Bridge and end at Priest Rapids Dam. Flights are conducted near noon with the intent to bracket the highest angle of the sun for optimum viewing conditions. Observers wear polarized glasses as necessary to reduce glare. All redds observed are documented by survey area on large format printed maps.

In addition to the visual counts, vertical aerial photographs were taken of the entire length of the Hanford Reach from Priest Rapids Dam downstream to the I-182 Bridge. Photographs were taken in conjunction with the final visual count conducted in 2013, with visual counts conducted while flying upstream and photographs taken when flying back downstream. Aerial photography has been conducted previously on the Hanford Reach, to compare counts between visual estimates and photographs (Visser et al. 2002). This previous effort was used to compare the two counting methods, but was not intended to provide a count or record of all Chinook spawning areas in the Hanford Reach; this previous survey covered approximately $60 \%$ of the known spawning areas of the Hanford Reach (Visser et al. 2002). The photographs taken during 2013 were intended to capture $100 \%$ of the Hanford Reach from Priest Rapids Dam to the I-182 Bridge so that all visible redds could be enumerated using a Geographic Information System (GIS).

Photographs were taken using a Nikon ${ }^{\mathrm{TM}}$ D7000 digital single lens reflex camera with a Tokina ${ }^{\mathrm{TM}}$ 11-16mm lens. The camera was mounted over an open hatch in the bottom of the aircraft (Figure 3 ) on a camera mount provided by Bergstrom Aircraft. The camera was wrapped in plastic for protection from engine exhaust and residue. The aircraft was flown at $161 \mathrm{kph}(100 \mathrm{mph})$ at an elevation of $823 \mathrm{~m}$ $(2700 \mathrm{ft})$ above ground level. The pilot aligned the plane with the center of the river channel and kept the airplane as level as possible. The camera's interval timer was set to automatically take a photo every 7 seconds for the duration of the flight from Priest Rapids Dam to the I-182 Bridge. This produced photographs that captured the entire width of the Columbia River, and overlapped by approximately two-thirds. 
Camera settings were as follows:

- Zoom at $13.5 \mathrm{~mm}$

- Focus set to manual and $\infty$

- $\quad$ Shutter speed priority selected and set at $1 / 1000$ s

- Aperture automatically ranged from 2.8 to 6.3

- ISO set at automatic but was generally 400

- File format was large JPGs

The pictures taken in 2013 were georeferenced using a GIS. The location of each fall Chinook salmon redd was then digitized.

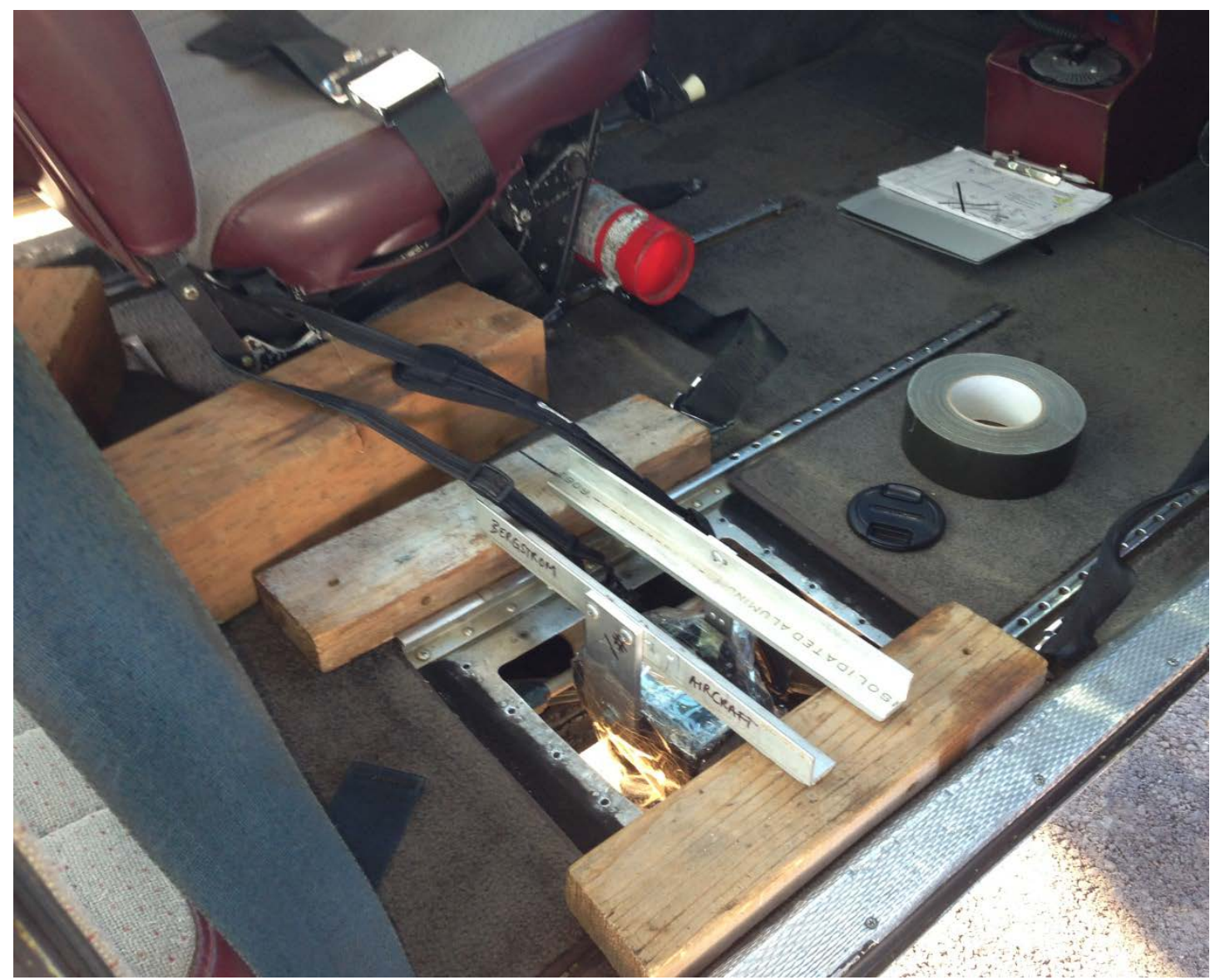

Figure 3. Digital Camera Mounted Over Airplane Hatch

\subsection{Results}

Three aerial surveys were completed along the length of the Hanford Reach during 2013. The first survey was performed on October 20 , the second on November 10 , and the third on November 21 . The 
flight conducted on November 21 also included aerial photography of the entire Hanford Reach. The counts performed by survey area for each flight are shown in Table 1. The maximum count describes the highest number of redds documented in a survey area within any single flight. The visual redd count total is calculated by summing the maximum redd count from each survey area and this equaled 17,398 in 2013. The number of redds counted within the newly defined sub-areas, coinciding with Hanford Site operational areas, is shown in Table 2.

Table 1. Summary of Fall Chinook Visual Aerial Redd Counts for the CY2013 Aerial Surveys in the Hanford Reach, Columbia River

\begin{tabular}{|c|c|c|c|c|c|}
\hline Area & Description & $10 / 20 / 2013$ & $11 / 10 / 2013$ & $11 / 21 / 2013$ & $\begin{array}{l}\text { Maximum } \\
\text { Count }\end{array}$ \\
\hline 0 & Islands 17-21 (Richland) & 0 & 0 & 0 & 0 \\
\hline 1 & Islands 11-16 & 1 & 708 & 798 & 798 \\
\hline $1 a$ & Savage Island/Hanford Slough & 0 & 0 & 0 & 0 \\
\hline 2 & Islands 8-10 & 27 & 1,835 & 2,200 & 2,200 \\
\hline 3 & Near Island 7 & 0 & 471 & 655 & 655 \\
\hline 4 & Island 6 (lower half) & 3 & 2,338 & 3,340 & 3,340 \\
\hline 5 & Island 4, 5 and upper 6 & 4 & 2,560 & 2,650 & 2,650 \\
\hline 6 & Near Island 3 & 2 & 800 & 1,000 & 1,000 \\
\hline 7 & Near Island 2 & 13 & 1,320 & 1,700 & 1,700 \\
\hline 8 & Near Island 1 & 0 & 680 & 900 & 900 \\
\hline $8 a$ & Upstream of Island 1 to Coyote Rapids & 0 & 0 & 0 & 0 \\
\hline 9 & Near Coyote Rapids & 0 & 463 & 520 & 520 \\
\hline $9 a$ & $\begin{array}{c}\text { Upstream of Coyote Rapids to China } \\
\text { Bar }\end{array}$ & 0 & 0 & 0 & 0 \\
\hline China Bar & China Bar/Midway & 2 & 80 & 100 & 100 \\
\hline 10 & Near Vernita Bar & 11 & 2,630 & 3,505 & 3,505 \\
\hline 11 & Near Priest Rapids Dam & 0 & 24 & 30 & 30 \\
\hline & TOTAL & 63 & 13,909 & 17,398 & 17,398 \\
\hline
\end{tabular}

Table 2. Summary of Fall Chinook Visual Aerial Redd Counts for the CY2013 Aerial Surveys by Operational Area Sub-sections

\begin{tabular}{|c|r|r|r|r|}
\hline Hanford Site Sub-Area & $\mathbf{1 0 / 2 0 / 2 0 1 3}$ & $\mathbf{1 1 / 1 0 / 2 0 1 3}$ & $\mathbf{1 1 / 2 1 / 2 0 1 3}$ & Maximum Count \\
\hline 300 Area & 0 & 0 & 0 & 0 \\
\hline Dunes & 0 & 0 & 0 & 0 \\
\hline $100-\mathrm{F}$ & 0 & 471 & 655 & 655 \\
\hline $100-\mathrm{H}$ & 4 & 2,560 & 2,650 & 2,650 \\
\hline $100-\mathrm{D}$ & 0 & 680 & 900 & 000 \\
\hline $100-\mathrm{N}$ & 0 & 0 & 0 & 0 \\
\hline $100-\mathrm{K}$ & 0 & 0 & 0 & 520 \\
\hline $100-\mathrm{B} / \mathrm{C}$ & 0 & 463 & 520 & 4,725 \\
\hline TOTAL & 4 & 4,174 & 4,725 & \\
\hline
\end{tabular}


HNF-56707

Revision 0

Aerial photographing began at Priest Rapids Dam and continued down the Hanford Reach to the I-182 Bridge. A total of 299 photographs were taken. The photographs were georeferenced so they overlapped along the entire length of the survey area (Figures $4 \& 5$ ). Light and weather conditions were ideal for photography, and redds were readily visible in the photographs (Figure 6). Each redd appeared as a light patch in the photographs taken. All redds that were visible in the photographs were digitized using a GIS and the initial aerial photograph redd count was 25,723.

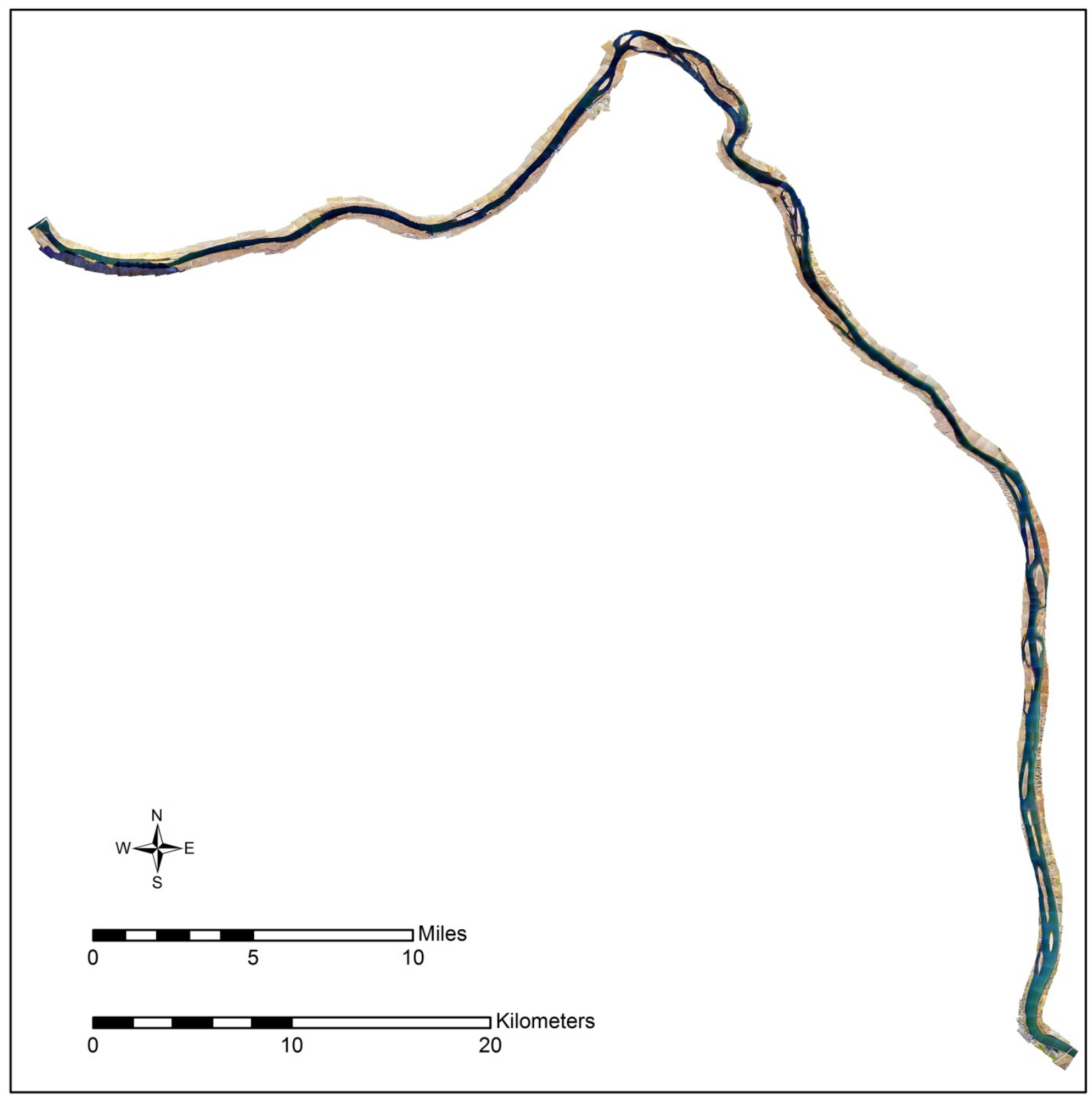

Figure 4. Georeferenced Aerial Photographs of the Hanford Reach Taken During 2013 
HNF-56707

Revision 0

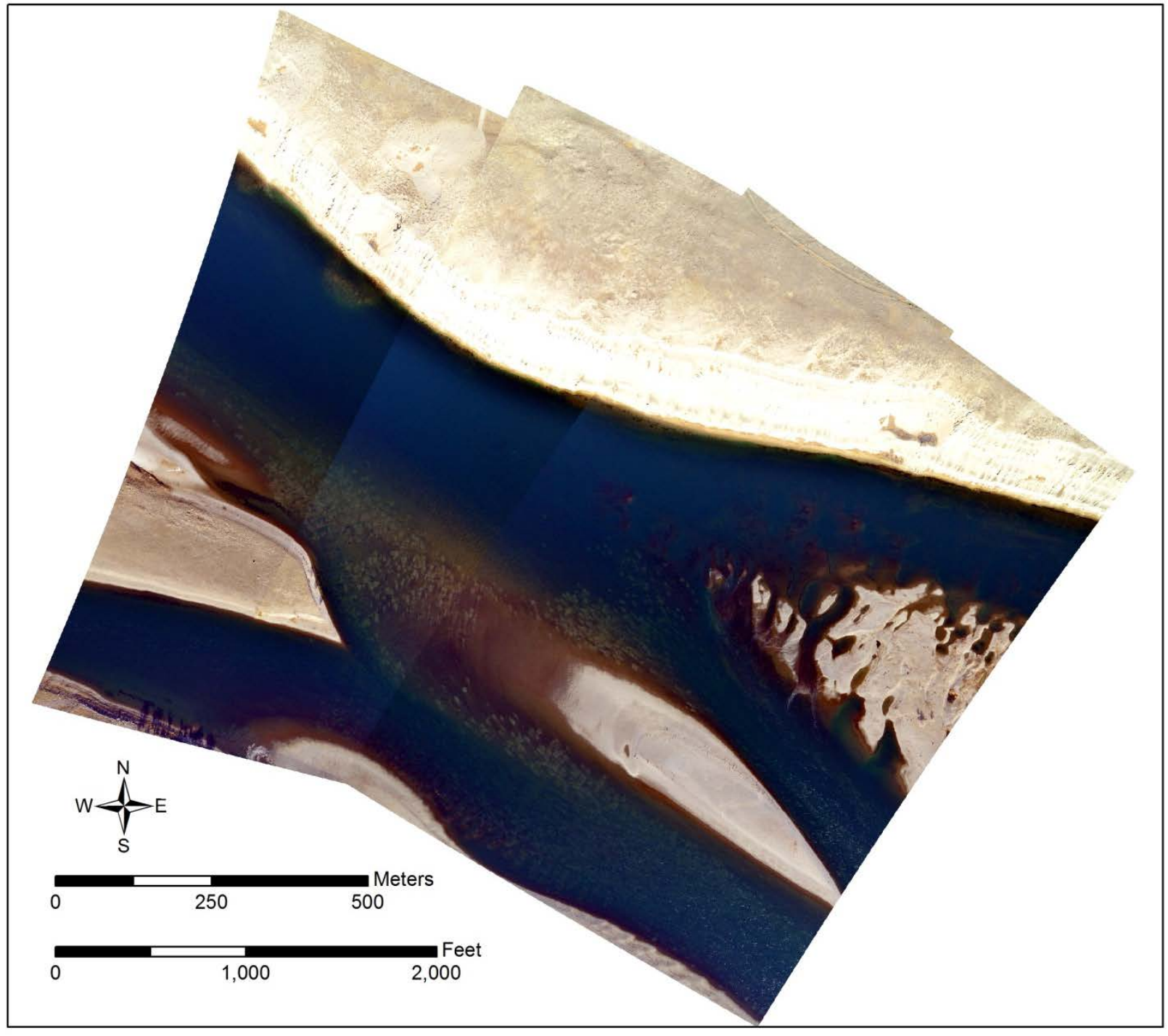

Figure 5. Three Overlapping Georeferenced Aerial Photographs from 2013 


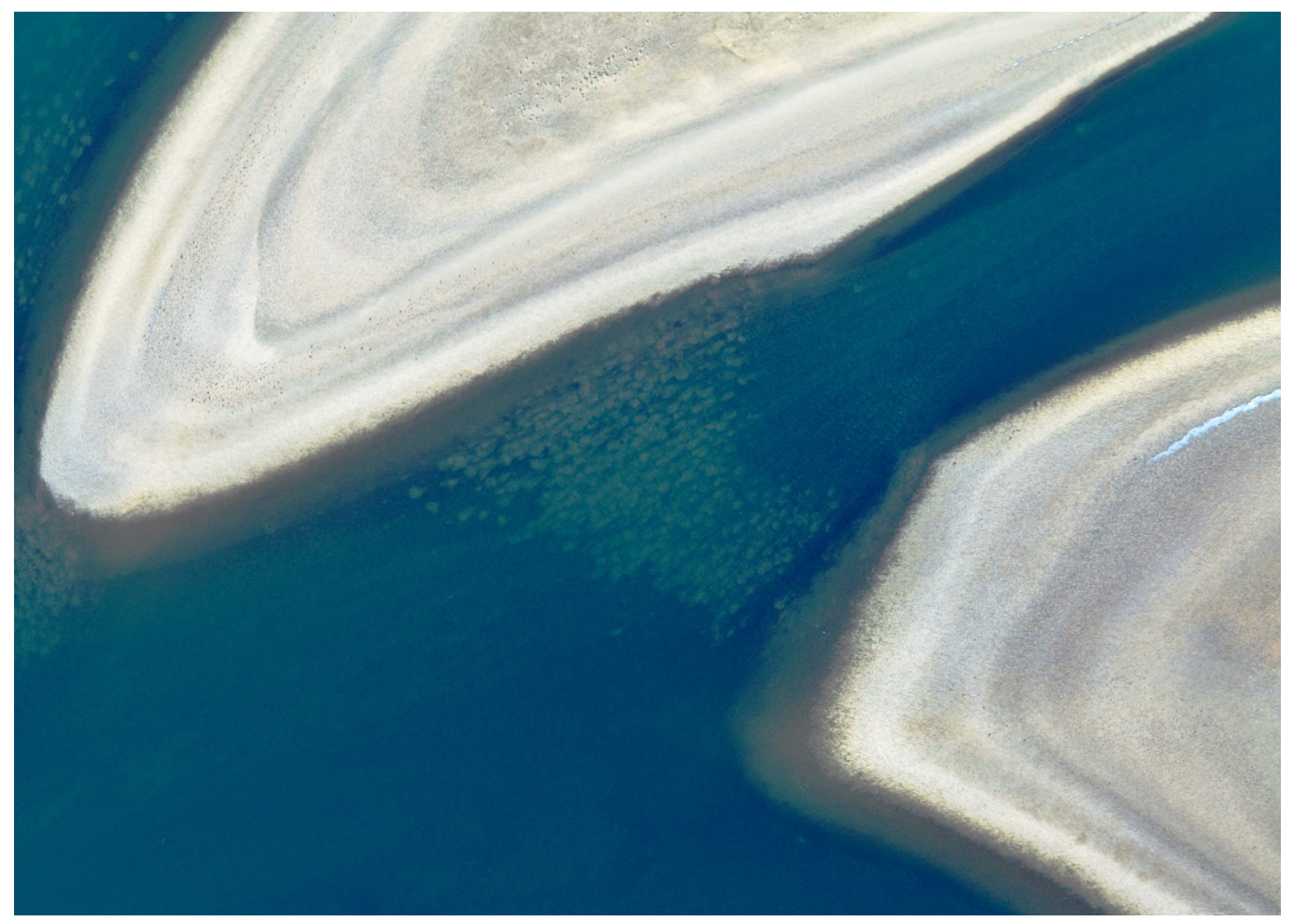

Figure 6. Aerial Photograph Taken in $\mathbf{2 0 1 3}$ of Redds Near Island $\mathbf{2}$ in the Hanford Reach (Image Cropped to Better Display Redds)

Shadows from Umtanum Ridge impeded the visibility of redds in a small portion of the Vernita Bar, and visibility was also limited where redd clusters extended into deep water. Redds were visible in water up

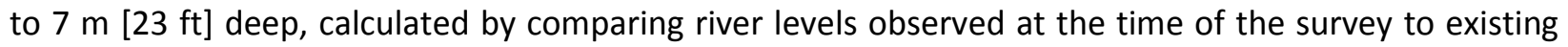
bathymetry data. A sediment plume was visible along the Franklin County (eastern) shoreline of the river starting near the White Bluffs irrigation return extending downstream along that shoreline to the City of Pasco. However, this plume did not likely obscure any redds.

Although the photographs captured the entire length of the Hanford Reach of the Columbia River, some small sections (photo gaps) along the shoreline were just out of the frame in a few locations. The photographs were planned to encompass the entire width of the river along the entire survey area, but the tolerance for divergence from the center of the channel was relatively small for the widest sections of the river. This was intended to maximize the resolution and quality of the photographs, but did result in some photo gaps. We determined that redds could be present in some of the photo gaps. This was determined based on the presence of redds adjacent to the photo gaps, or where photo gaps overlapped with historical spawning areas. In order to estimate the number of redds in the photo gaps, the density of redds was calculated (redds per $\mathrm{m}^{2}$ ) in the areas adjacent to the photo gaps, and this density was extrapolated over the portion of photo gaps that were determined to potentially contain 
redds. This process resulted in the addition of 470 redds to the overall aerial photograph redd count. Thus, the total aerial photograph redd count, including the digitized redds and the estimated number of redds missed in the photo gaps, is $26,193$.

\subsection{Discussion}

Aerial counts of fall Chinook redds have been conducted in the Hanford Reach since 1948 to generate annual indices of abundance and distribution. This was the third year that these counts have been conducted under the Mission Support Alliance (MSA) contract. Because long term trends in both redd abundance and distribution are important monitoring components, several steps were taken to ensure compatibility and consistency with past efforts.

These included:

1) Thoroughly reviewing and adopting past monitoring protocols.

2) Coordination/training with former redd count personnel to ensure consistency with past efforts.

3) Coordination and exchange of information with the Washington Department of Fish and Wildlife (WDFW) and with the Grant County Public Utility District (GCPUD) to ensure consistency with the ongoing Hanford Reach Fall Chinook Protection Program.

4) Using maps detailing the entire survey reach as well as all historical sub-areas and spawning sites both as in-flight guidance documents and as field data recording forms.

5) Using the same air service, airplane, and pilots in 2013 that were used in previous years.

The peak annual visual redd count for $2013(17,398)$ was almost double the count made in $2012(8,368)$, and far exceeded the all-time highest count of 9,465 (year 2003), and was well in excess of the average for the previous ten years $(7,271)$. Viewing conditions were good to excellent during all three surveys which undoubtedly contributed to the high number of redds counted in 2013. With the use of aerial photography, a total of 26,193 redds were estimated for the Hanford Reach in 2013. The aerial redd count total was 1.5 times the visual redd count for 2013. This relationship would likely vary with escapement level, because visual redd counting accuracy drops with increasing redd patch size, resulting in underestimation (Visser et al. 2002). This was the first time an estimate was made for the entire Hanford Reach using aerial photography, so the number cannot be compared to any previous estimates. The ideal viewing conditions also allowed for the detection, using photographs, of redds in deep water

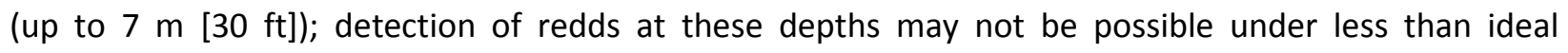
conditions. The primary driving factor for the extremely high number of redds observed in 2013 was the record escapement of adult fall Chinook to the Hanford Reach for 2013, which totaled 157,484 (Hoffarth 2014). This is 68,184 higher than the previous maximum of 89,300 that occurred in 2003 . The historical trend in visual redd counts since 1948 is shown in Figure 7. 


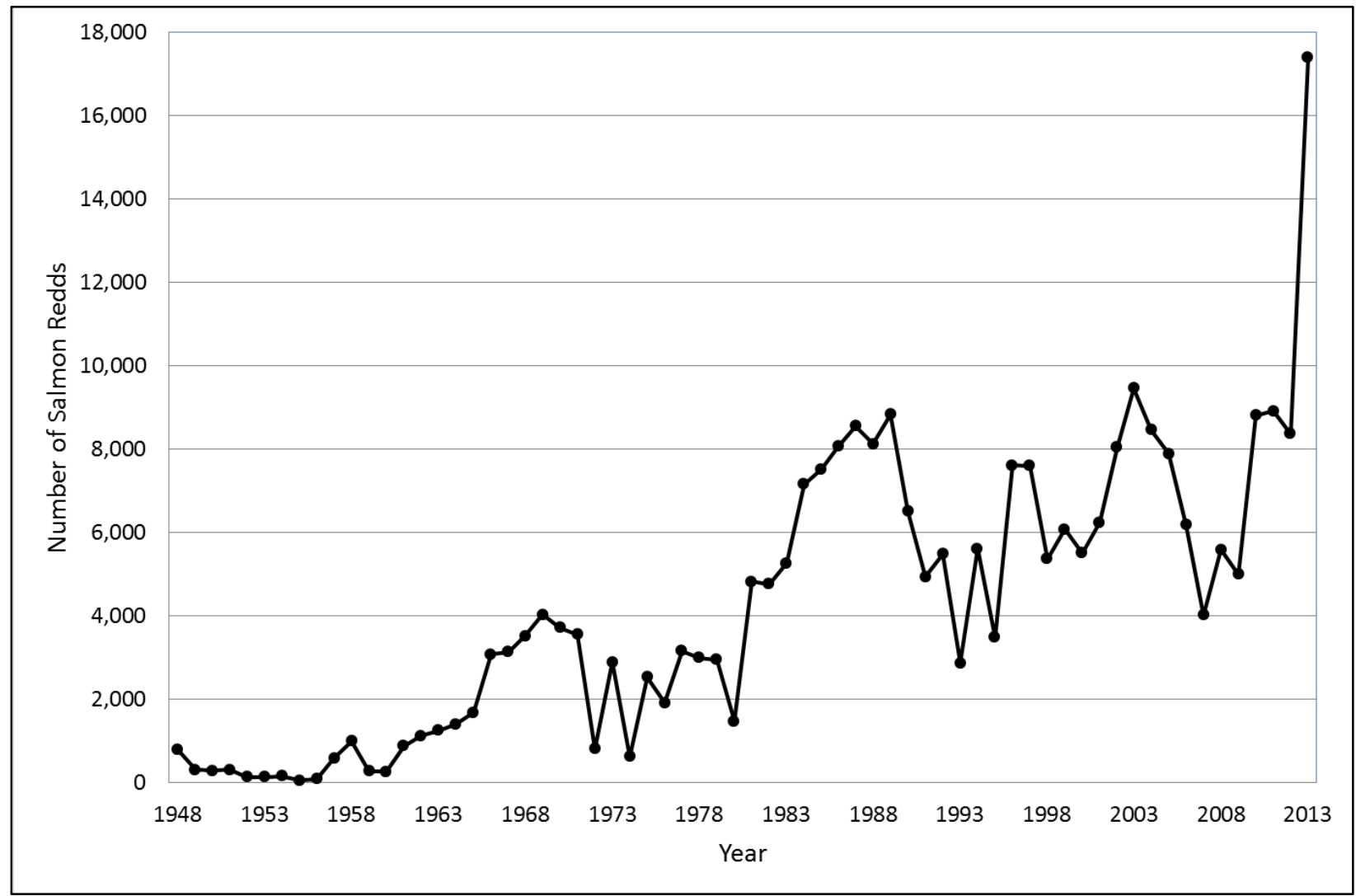

Figure 7. Visual Hanford Reach Fall Chinook Salmon Redd Counts 1948 to 2013

The relationship between annual fall Chinook redd counts collected by the DOE-RL and the adult fall Chinook escapement estimates generated annually for the Hanford Reach by WDFW fitted with a line to approximate the overall long-term trend in the data is depicted in Figure 8. The relationship appears to be linear, however additional data at escapement levels exceeding 100,000 individuals would more thoroughly show whether the correlation remains linear at the high escapement levels.

During visual counts, redds are enumerated individually, and in groups of 10 and 50. During periods of extensive spawning, counting redds in groups of 50 is often necessary but this procedure requires a higher level of count estimation on the part of the surveyor which could further result in an under estimate of the actual number of redds. Counting redds in deep water, where they are difficult see, is another factor that has been well documented (Dauble and Watson 1990). Visual redd counts are generally limited to water depths up to 3-4 meters, but the aerial photography produced in 2013 allowed for detection of redds in up to 7 meters of water which explains, in part, the higher number of redds documented using photography. 


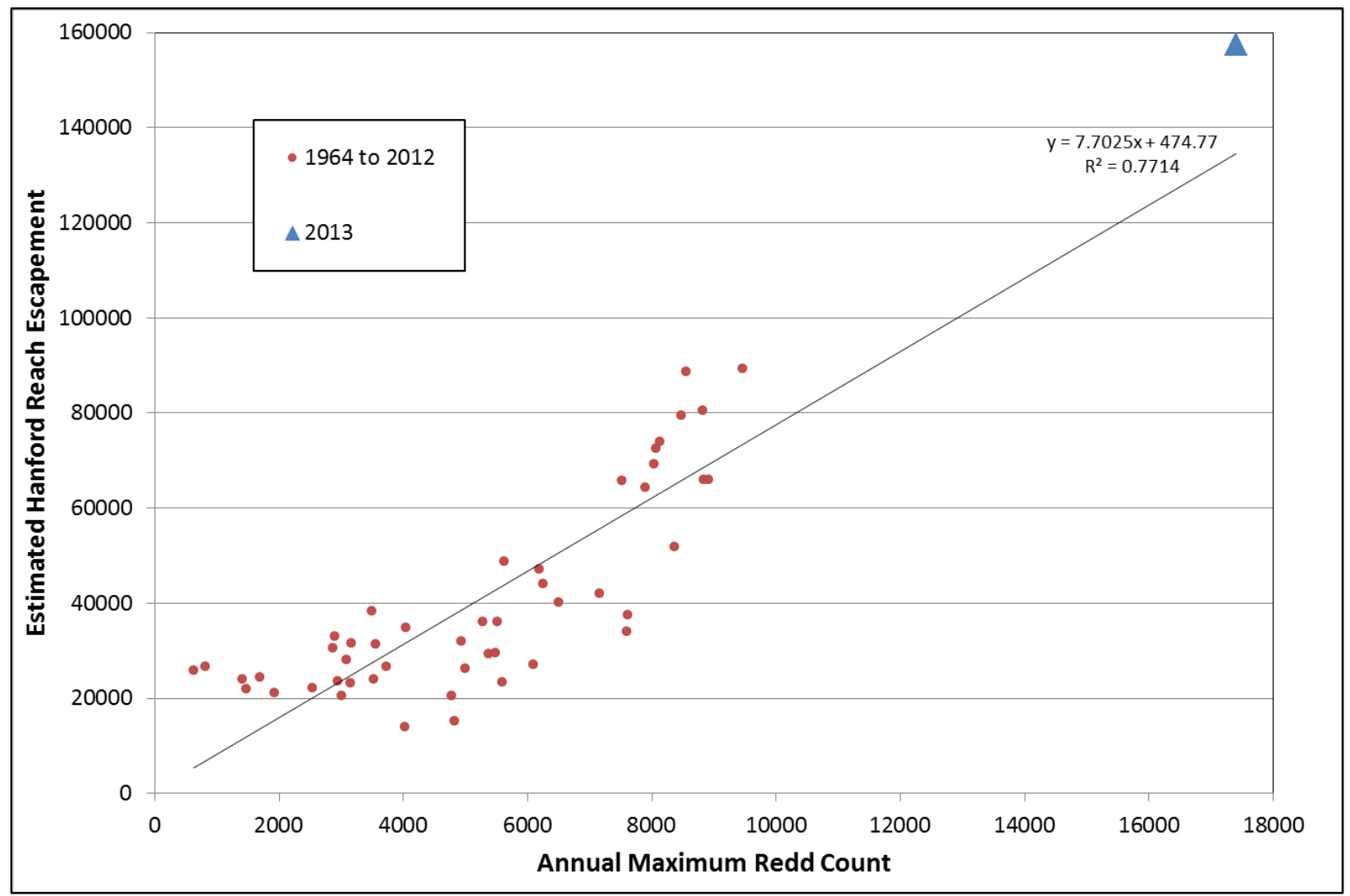

\section{Figure 8. Relationship Between Annual Visual Fall Chinook Maximum Redd Count and} Estimated Hanford Reach Escapement 1964 to 2013

Redd superimposition was prevalent in the major spawning areas along the entire Hanford Reach. In areas with significant redd superimposition, it was not possible to delineate individual redds, even using the aerial photographs. In these areas, points were digitized at approximately the highest density observed in areas where individual redds were still visible. This likely resulted in an underestimation of the number of redds in areas with significant levels of superimposition (Figure 9). 


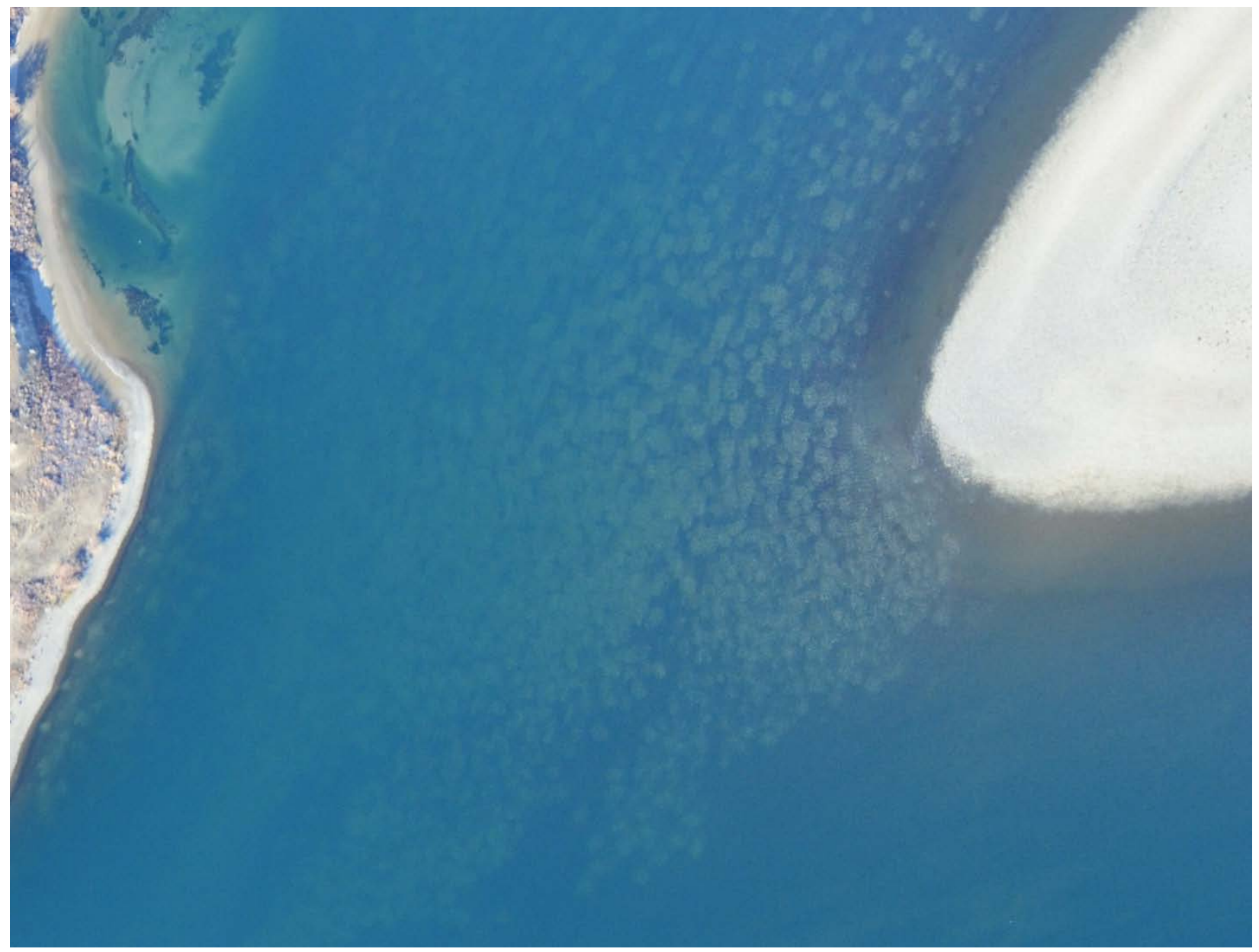

\section{Figure 9. Redd Cluster with High Degree of Superimposition (Image Cropped to Better Display Redds)}

The presence of contaminated groundwater at the Hanford Site is well documented (DOE/RL-2011-119). The historical areas where fall Chinook redds were observed in 2013 included locations where contaminated groundwater may be upwelling into the Columbia River. A total of 4,725 redds were documented from the visual counts, and 6,429 from the aerial photographs in the areas adjacent to Hanford Site groundwater contamination plumes. However, more research would be necessary to confirm the actual presence of contaminated groundwater upwelling within spawning areas or at individual redd locations.

At the bottom end of Homestead Island, an influx of sediment was visible in the river on November 21, 2013, that was not visible during the two previous flights. This sediment plume may have suppressed the level of spawning in this area and could affect the success of redds already constructed there.

Overall, photograph quality and redd visibility was outstanding for the entire 2013 dataset. The use of aerial photography was effective for recording the abundance of fall Chinook salmon redds along the Hanford Reach of the Columbia River. Weather typical in October and November can often make aerial 
surveys difficult. Common complicating factors include high winds, precipitation, low clouds, and fog. The aerial photography method is dependent on ideal viewing conditions; and in other years these conditions may not occur during the peak spawning window, potentially rendering this method unusable.

This dataset also provides a record of the location of all spawning activity that occurred in the Hanford Reach in 2013. Digitized redd locations of the Hanford Reach for 2013 are provided in Figures 10, 11 and 12. Because of the record escapement that occurred for the Hanford Reach in 2013, this dataset likely represents most or all of the locations that are used by fall Chinook for spawning in this section of the Columbia River. Therefore, these points were used to generate a new map of all spawning areas for fall Chinook on the Hanford Reach (Figure 13, 14, and 15). While a layer showing spawning areas was previously available (pre-2013 Fall Chinook Spawning Areas), these polygons were not based on digitized redd locations, but on experienced surveyor's knowledge of major spawning areas. The resulting polygons will be extremely useful for avoiding impacts to these areas from Hanford Site activities and to document changes that may occur due to slumping along the Grant/Franklin County shoreline of the Columbia River. The locations could also be used to determine if redds are being impacted by contaminated groundwater upwelling by comparing locations to known upwelling areas ( $\underline{\mathrm{WCH}-380})$. If redds are photographed and digitized in the future, those locations could be used to update the overall redd locations map for the Hanford Reach by combining the points from the separate survey years.

In addition to marking redd locations, redd density was analyzed as a parameter indicating habitat quality, assuming that the most highly sought habitats in the river attract the most spawning activity. Redd density varied between 0 and 375 redds per hectare in 2013 (Figures 16, 17, and 18). 
HNF-56707

Revision 0

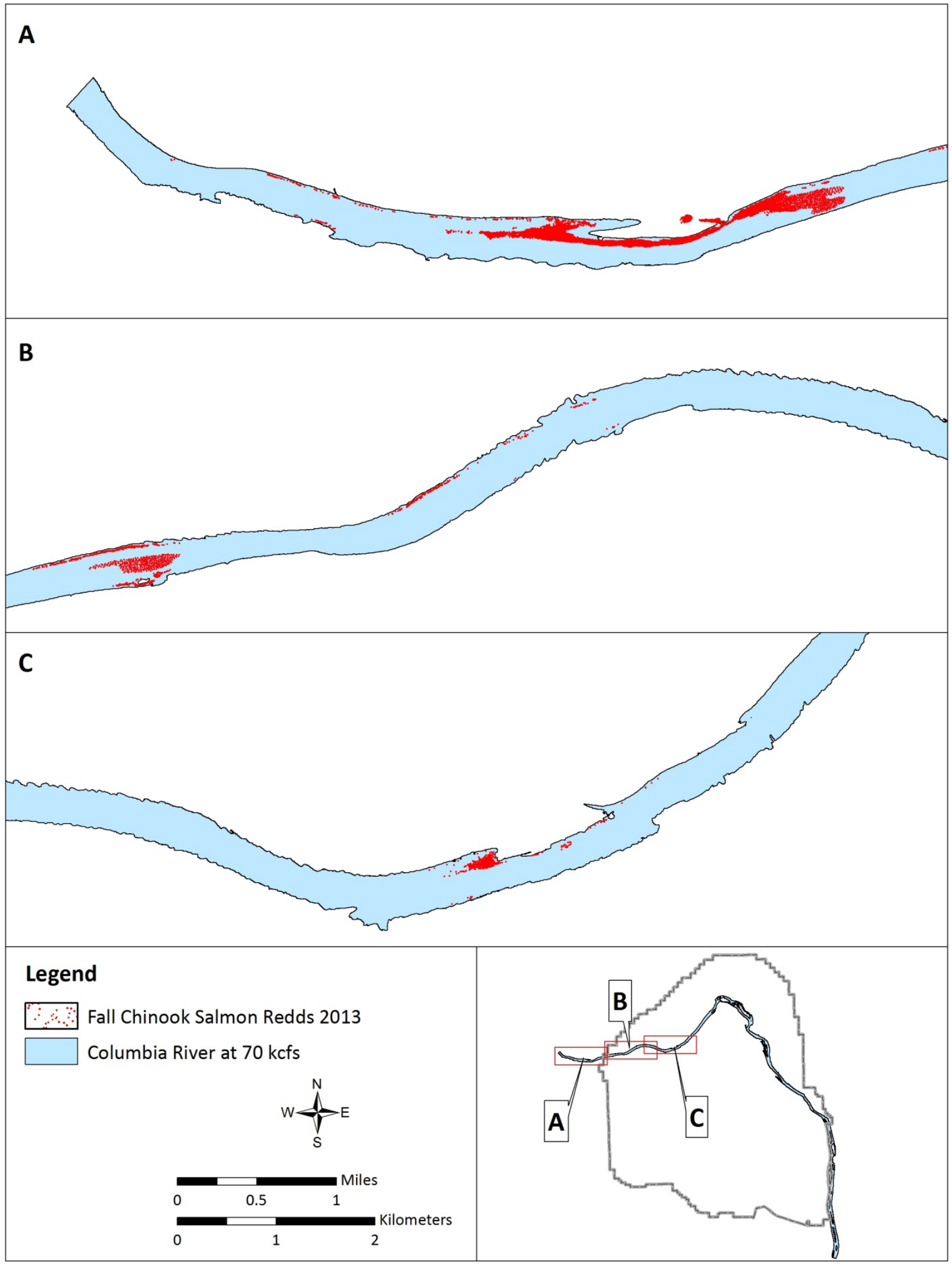

Figure 10. Upper Hanford Reach Digitized Redd Locations for 2013 
HNF-56707

Revision 0

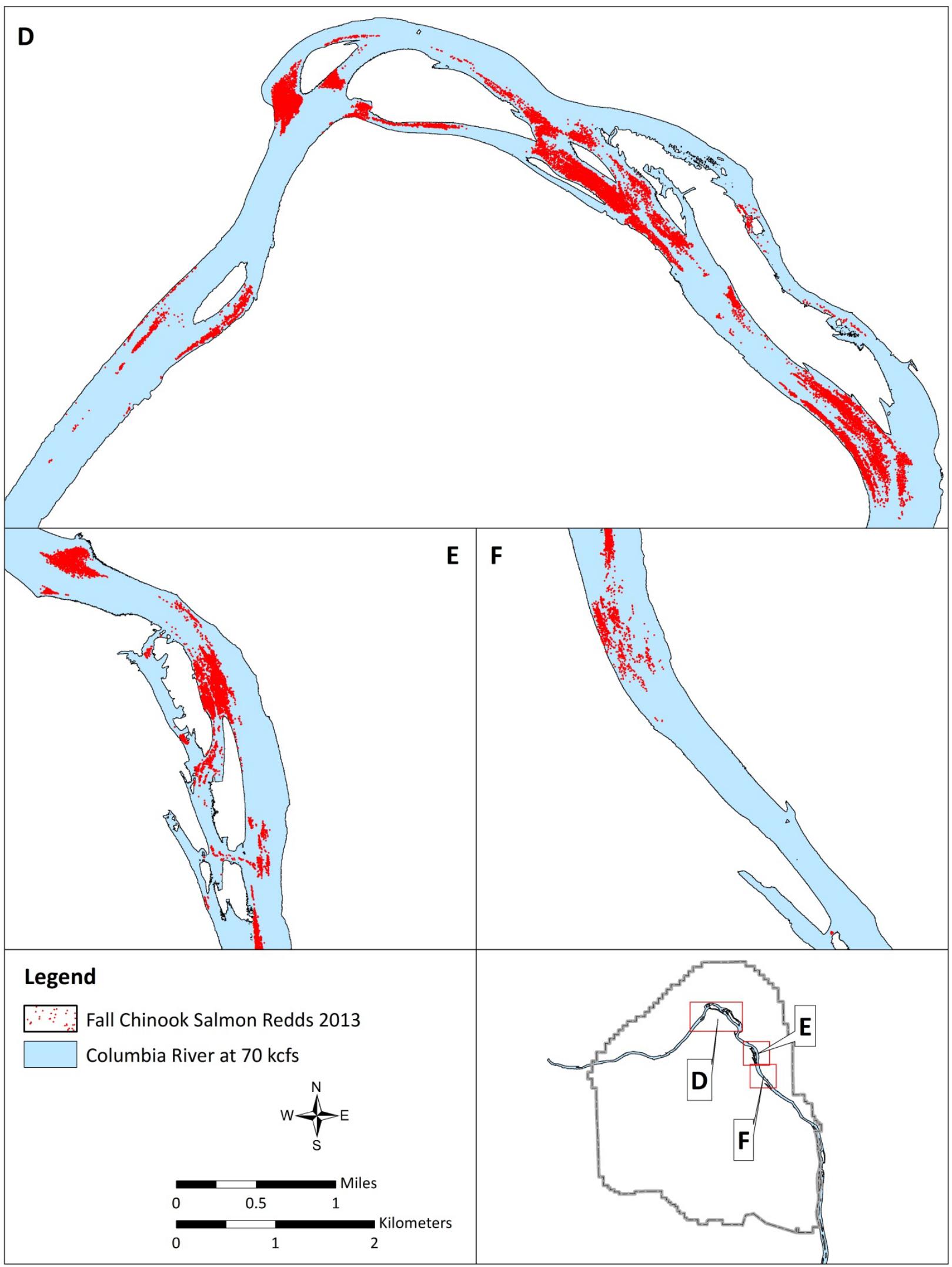

Figure 11. Middle Hanford Reach Digitized Redd Locations for 2013 
HNF-56707

Revision 0

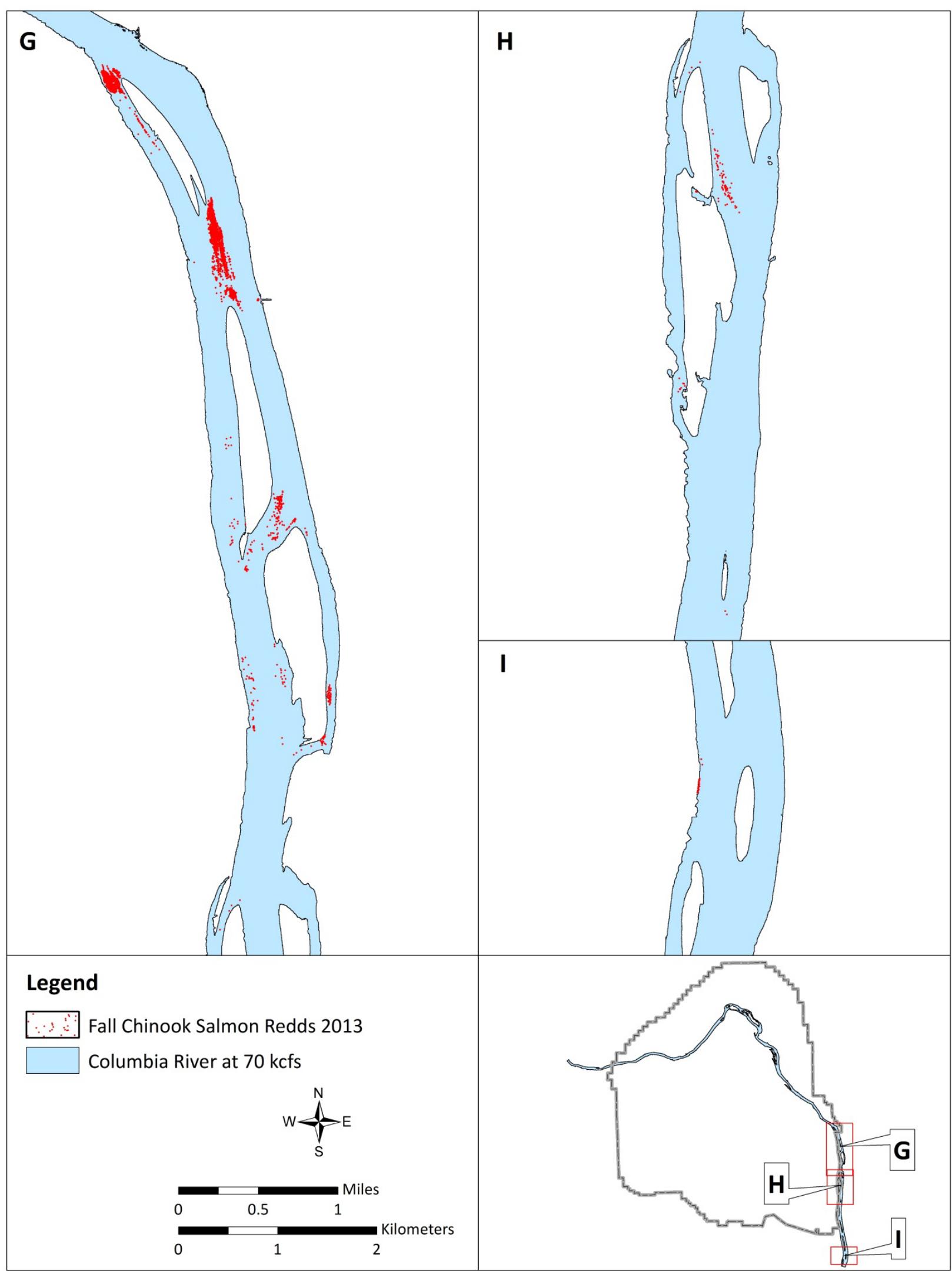

Figure 12. Lower Hanford Reach Digitized Redd Locations for 2013 


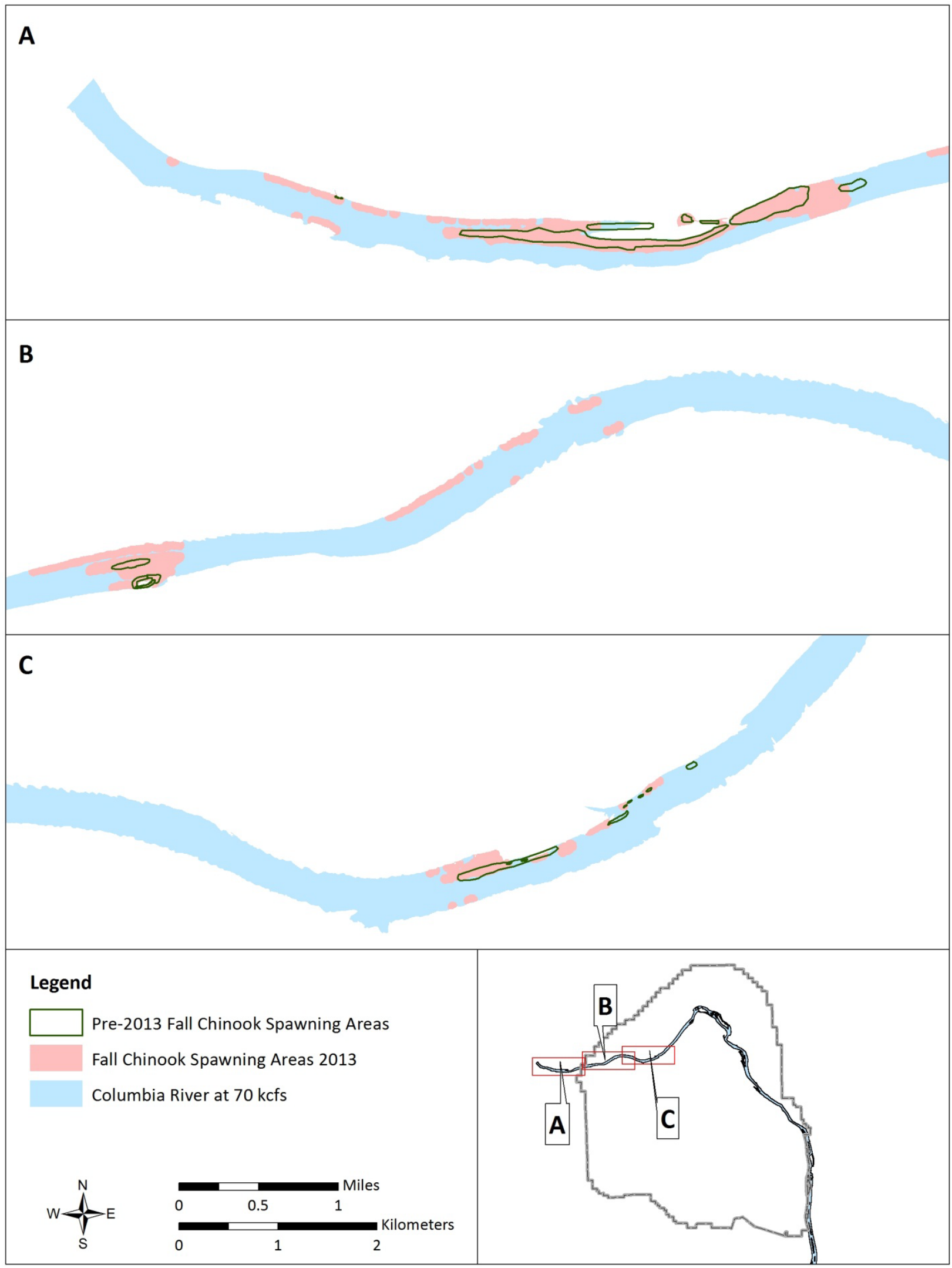

Figure 13. Upper Hanford Reach Fall Chinook Spawning Areas Pre-2013 and From 2013 
HNF-56707

Revision 0

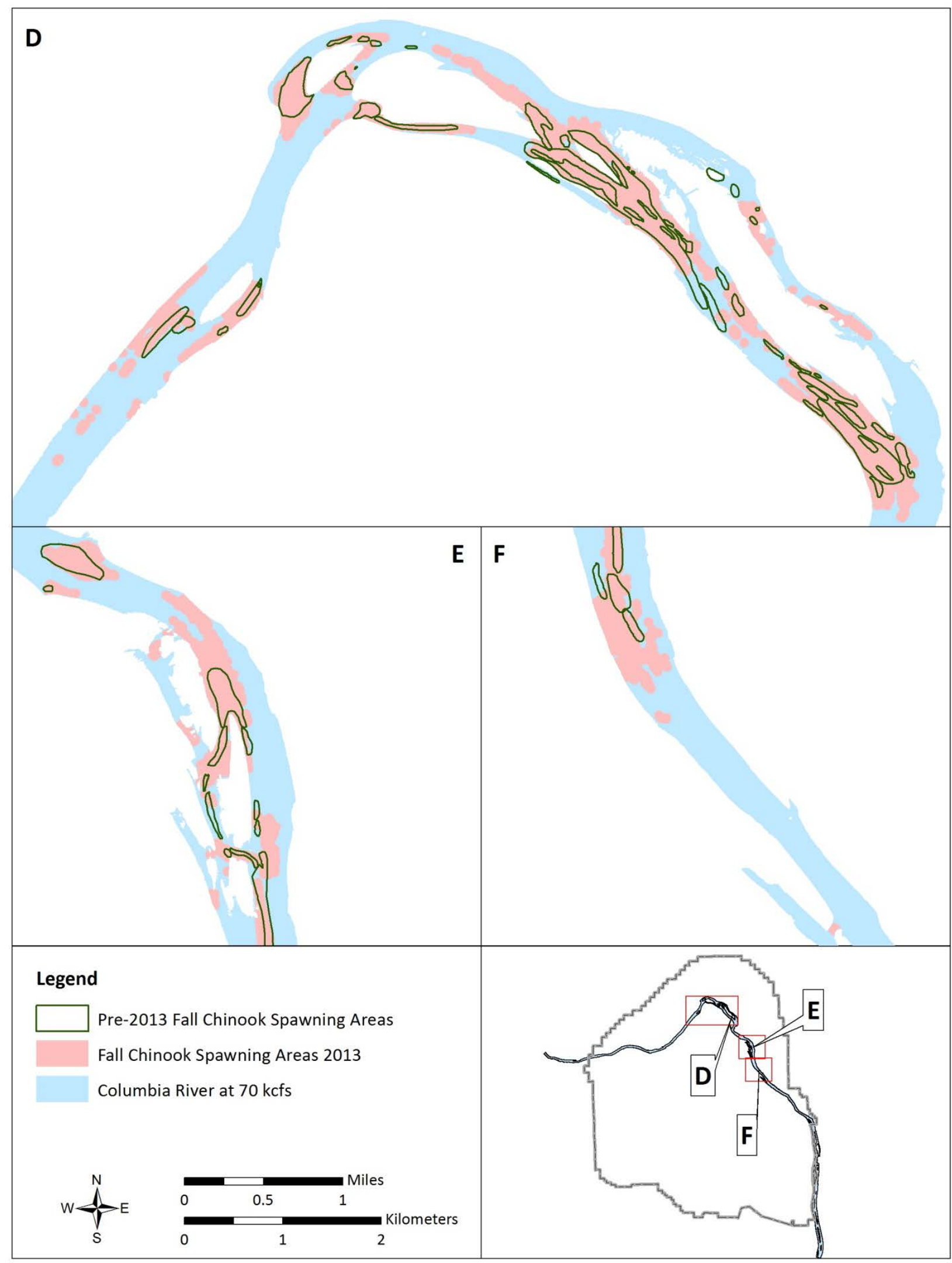

Figure 14. Middle Hanford Reach Fall Chinook Spawning Areas Pre-2013 and From 2013 
HNF-56707

Revision 0

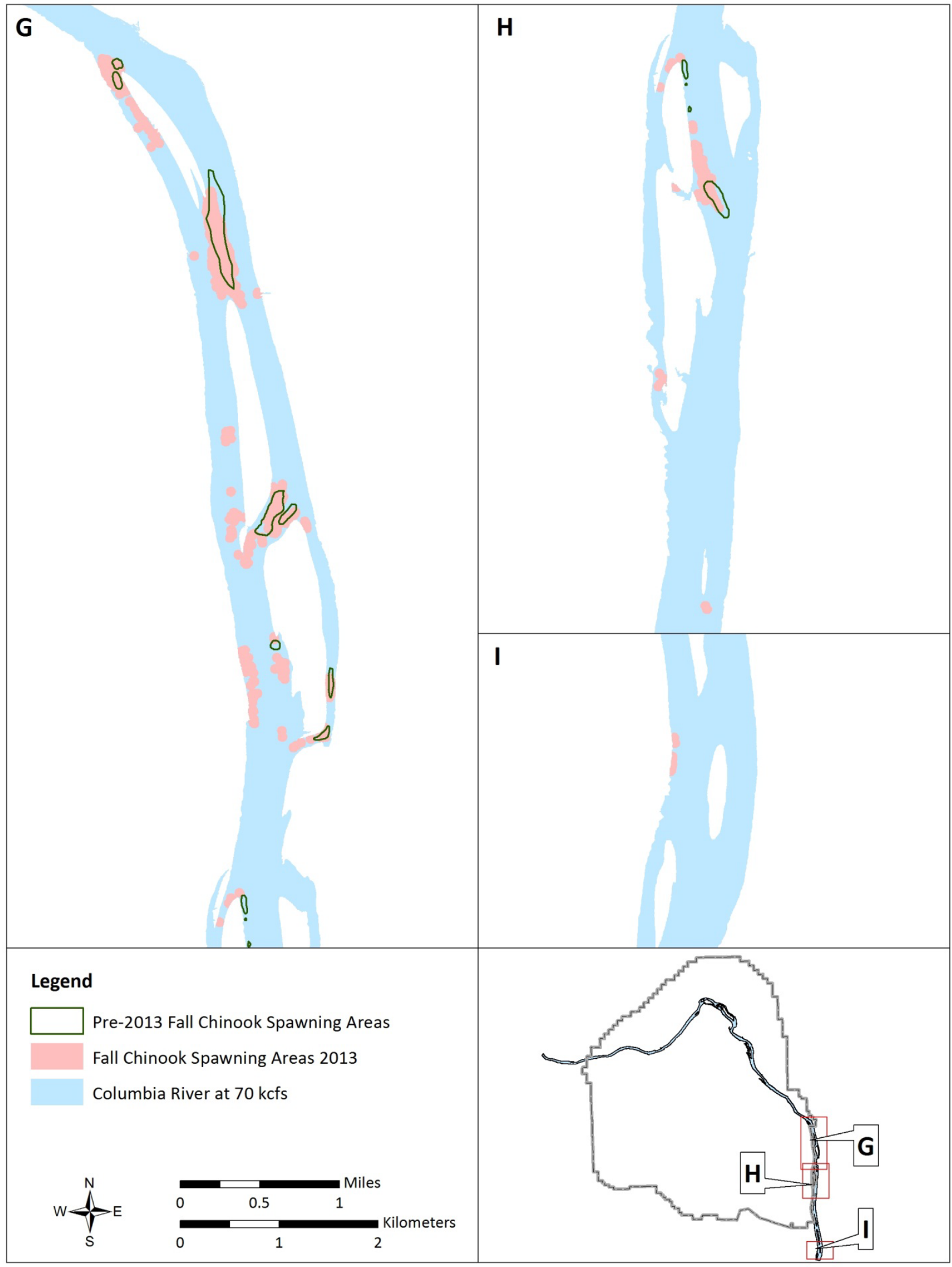

Figure 15. Lower Hanford Reach Fall Chinook Spawning Areas Pre-2013 and From 2013 


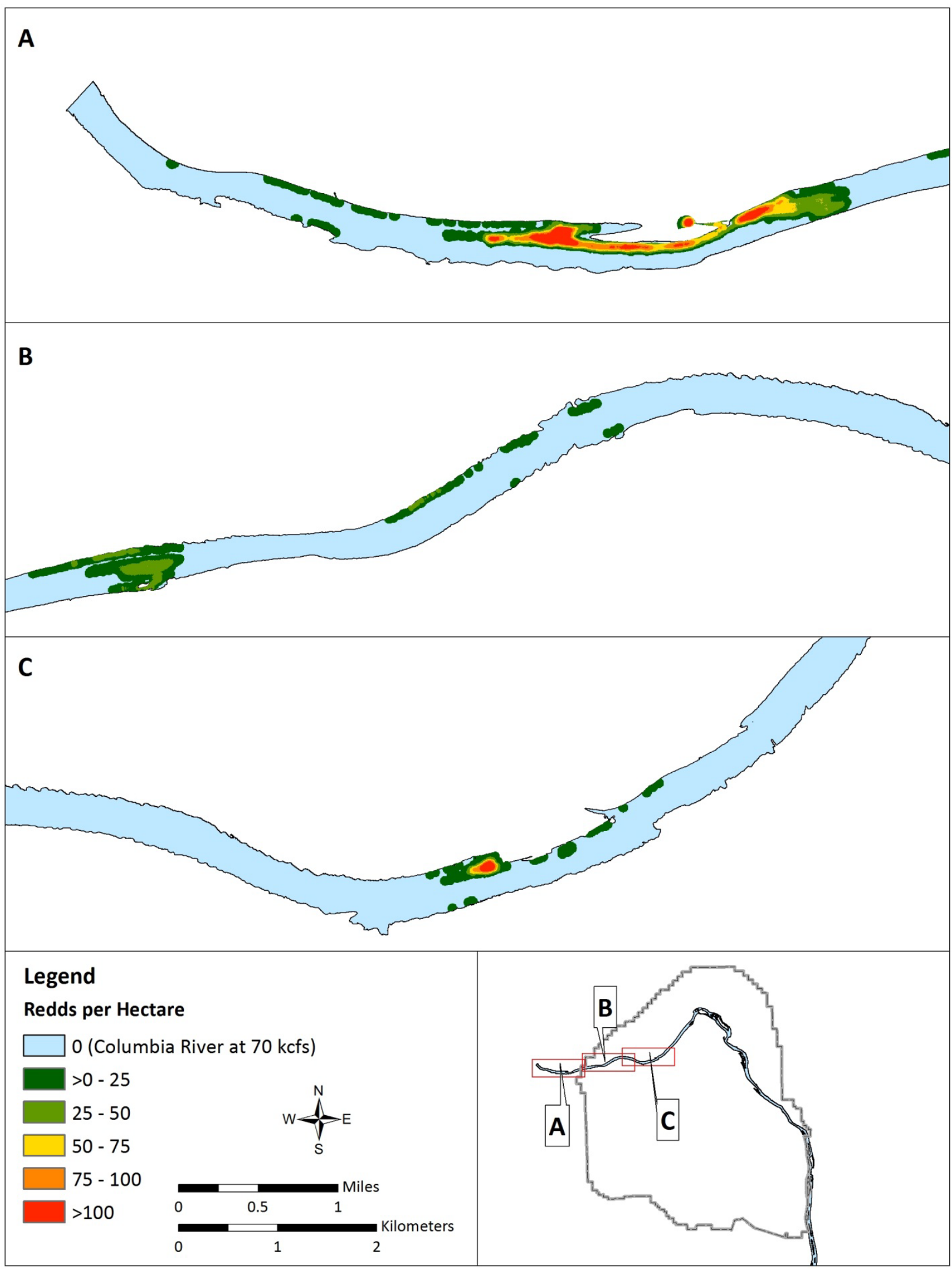

Figure 16. Upper Hanford Reach Redd Density for 2013 
HNF-56707

Revision 0

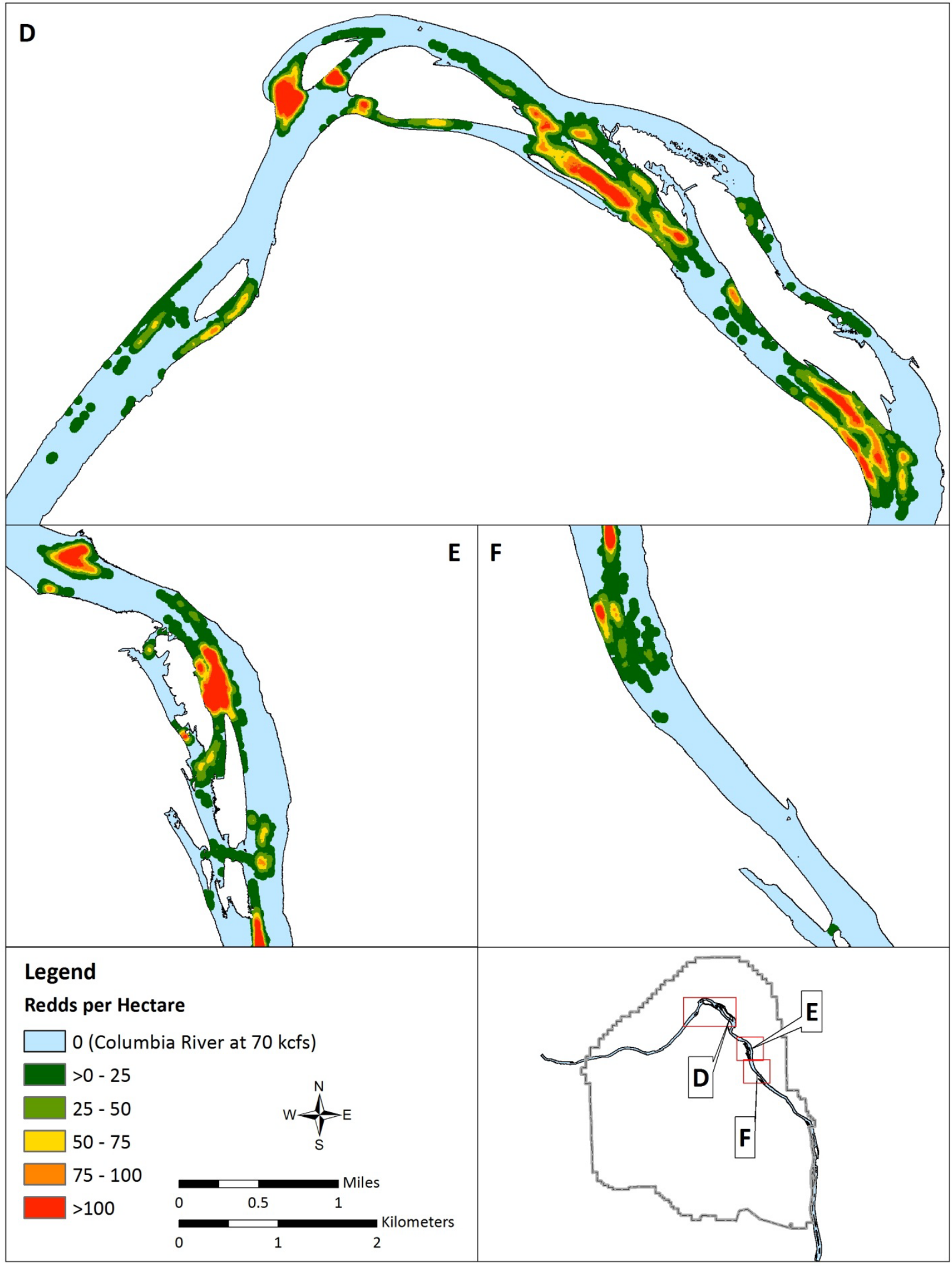

Figure 17. Middle Hanford Reach Redd Density for 2013 
HNF-56707

Revision 0

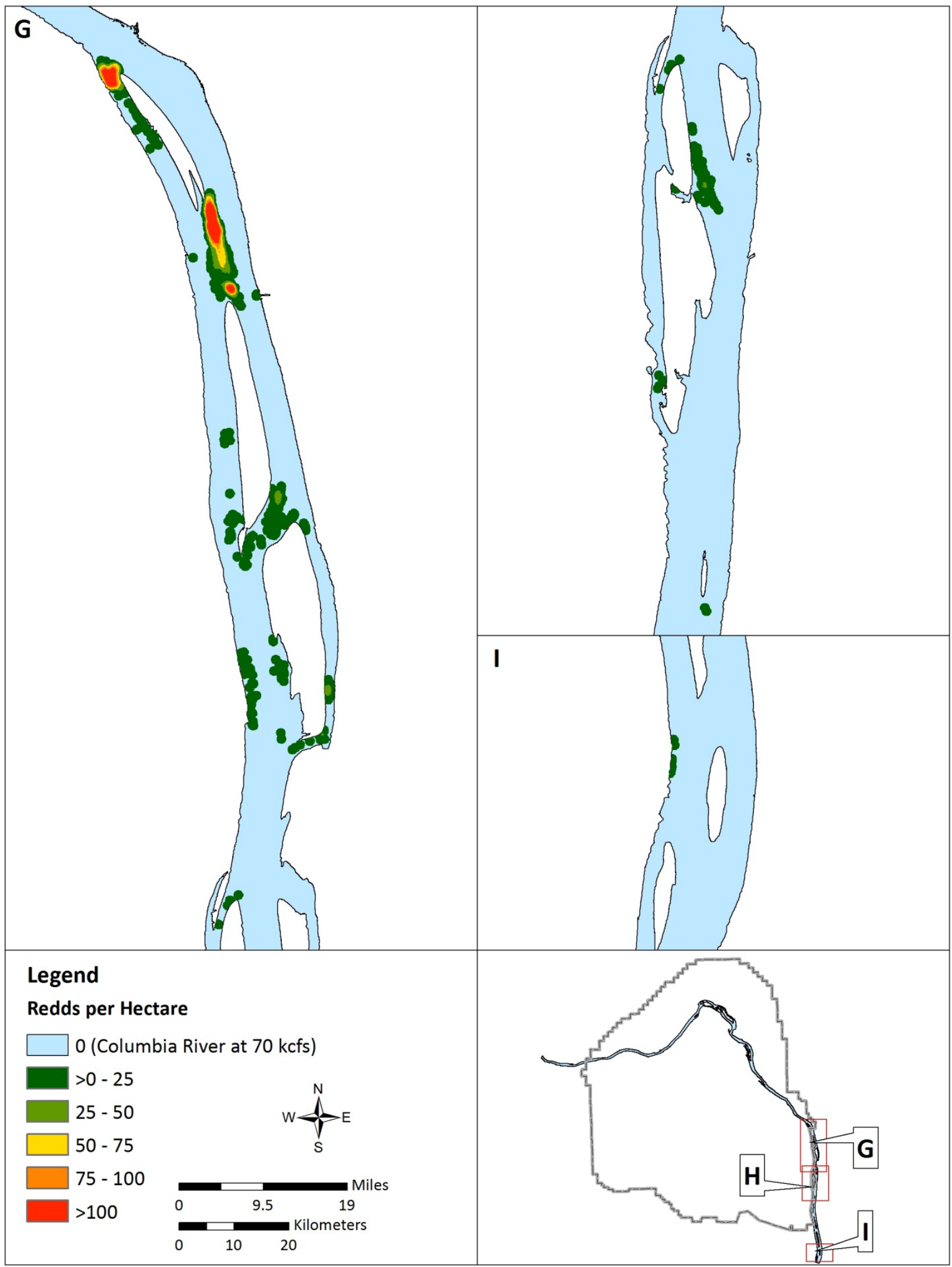

Figure 18. Lower Hanford Reach Redd Density for 2013 
The size of individual redds could be measured using GIS because the images were georeferenced. Chinook salmon redd sizes range between $2 \mathrm{~m}^{2}$ and $6 \mathrm{~m}^{2}\left[22 \mathrm{ft}^{2}\right.$ to $64 \mathrm{ft}^{2}$ ] in other river systems; however, redd sizes measured on Vernita Bar, on the Hanford Reach, between 1978 and 1983 averaged $17 \mathrm{~m}^{2}$ [183 $\mathrm{ft}^{2}$ ] and ranged from $1.3 \mathrm{~m}^{2}$ to $33 \mathrm{~m}^{2}$ [14 $\mathrm{ft}^{2}$ to $355 \mathrm{ft}^{2}$ ] (Chapman et. al 1986). Individual patches of disturbed peryphyton, which were enumerated as a single redd in 2013, ranged from two to six meters across in 2013 (perpendicular to the direction of flow). Disturbed areas of the redds visible in the aerial photos were generally round, so redds measured in 2013 ranged in size from approximately $3 \mathrm{~m}^{2}$ to $28 \mathrm{~m}^{2}$ [32 $\mathrm{ft}^{2}$ to $301 \mathrm{ft}^{2}$ ] which is within the range described by Chapman et. al (1986). This comparison was necessary to ensure that it was accurate to enumerate the very large redds observed in 2013 as single redds and not as clusters of two or more redds.

The largest single section of the river that was missed in the photographs (photo gap) that also likely contained redds was along the Benton County shoreline inside of Locke Island. Redds were observed to the edges of the photos along this area, and previous redd maps show redds in the area of the river that was not captured in the photographs. The area missed was approximately $70,102 \mathrm{~m}^{2}$. Based on an average calculated density of redds of one redd per $196 \mathrm{~m}^{2}$, we estimated the area contained 358 redds. A total of 13.8 hectares [34 acres] were missed in areas potentially containing redds, and a total of 470 redds were estimated in these areas. The 13.8 hectares represents $0.3 \%$ percent of the total river surface area at the 70 thousand cubic feet per second (kcfs) flow level. The remainder of the photo gap statistics and corresponding redd count estimates, by survey area and sub-area, are shown in Tables 3 and 4.

Table 3. Photo Gap Statistics by Area and Corresponding Redd Count Estimates

\begin{tabular}{|c|c|c|c|c|c|}
\hline \multirow[b]{2}{*}{ Area } & \multirow[b]{2}{*}{ Description } & \multicolumn{3}{|c|}{ River Surface Area at 70kcfs Flow Level (hectares) } & \multirow{2}{*}{$\begin{array}{c}\text { Number of Redds } \\
\text { Estimated in } \\
\text { Photo Gap Areas }\end{array}$} \\
\hline & & $\begin{array}{c}\text { Total River } \\
\text { Area }\end{array}$ & $\begin{array}{c}\text { Photo Gap } \\
\text { Area }\end{array}$ & $\begin{array}{c}\text { Photo Gap Area Potentially } \\
\text { Containing Redds }\end{array}$ & \\
\hline 0 & Islands 17-21 (Richland) & 787.3 & 29.2 & 0 & 0 \\
\hline 1 & Islands 11-16 & 929.1 & 59.4 & 5.0 & 14 \\
\hline 1a & Savage Island/Hanford Slough & 549.0 & 0 & 0 & 0 \\
\hline 2 & Islands 8-10 & 321.7 & 0 & 0 & 0 \\
\hline 3 & Near Island 7 & 104.8 & 0 & 0 & 0 \\
\hline 4 & Island 6 (lower half) & 290.1 & 6.0 & 1.4 & 69 \\
\hline 5 & Island 4, 5 and upper 6 & 197.3 & 19.5 & 7.4 & 387 \\
\hline 6 & Near Island 3 & 92.3 & 0 & 0 & 0 \\
\hline 7 & Near Island 2 & 109.0 & 2.2 & 0 & 0 \\
\hline 8 & Near Island 1 & 116.0 & 0 & 0 & 0 \\
\hline $8 a$ & Upstream of Island 1 to Coyote Rapids & 247.1 & 0 & 0 & 0 \\
\hline 9 & Near Coyote Rapids & 163.7 & 0 & 0 & 0 \\
\hline $9 a$ & Upstream of Coyote Rapids to China Bar & 340.2 & 0 & 0 & 0 \\
\hline China Bar & China Bar/Midway & 61.2 & 0 & 0 & 0 \\
\hline 10 & Near Vernita Bar & 216.6 & 0 & 0 & 0 \\
\hline 11 & Upstream of Vernita Bar to Priest Rapids Dam & 112.1 & 0 & 0 & 0 \\
\hline \multicolumn{2}{|r|}{ TOTALS } & 4637.6 & 116.4 & 13.8 & 470 \\
\hline
\end{tabular}


Table 4. Photo Gap Statistics by Sub-Area and Corresponding Redd Count Estimates

\begin{tabular}{|c|c|c|c|c|}
\hline \multirow[b]{2}{*}{ Area } & \multicolumn{3}{|c|}{ River Surface Area at 70kcfs Flow Level (hectares) } & \multirow[b]{2}{*}{ Number of Redds } \\
\hline & Total Area & Photo Gap Area & Photo Gap Area Potentially & \\
\hline $100-B / C$ & 131.5 & 0 & 0 & 0 \\
\hline $100-D$ & 116.0 & 0 & 0 & 0 \\
\hline $100-\mathrm{H}$ & 197.3 & 19.5 & 7.4 & 387 \\
\hline $100-\mathrm{F}$ & 75.1 & 0 & 0 & 0 \\
\hline Dunes & 258.8 & 0 & 0 & 0 \\
\hline $100-K$ & 124.7 & 0 & 0 & 0 \\
\hline $100-\mathrm{N}$ & 154.7 & 0 & 0 & 0 \\
\hline 300 Area & 309.8 & 4.0 & 0 & 0 \\
\hline \multicolumn{2}{|c|}{ TOTALS } & 23.5 & 7.4 & 387 \\
\hline
\end{tabular}

Using a global positioning system (GPS) during the flight with a line showing the center of the river would help avoid missing portions of the river in the aerial photographs. This would be especially useful on river corners and where islands divide the river channel. Flying higher or reducing the zoom of the lens would make the area captured by the photographs wider, and would allow for greater flexibility away from the center without missing portions of the river, but would reduce the quality of the photographs at the individual redd scale.

There are some locations where the historical spawning layer showed redds where none were observed in 2013. This could be due to changes occurring to the river from gravel deposition and scour, sedimentation, and sloughing along the Franklin/Grant county shoreline. There were, however, more and larger areas where spawning was observed in 2013 that were not captured in the historical spawning layer.

The aerial method was completed without additional flights or flying time, and only required the removal of a hatch in the airplane. The aerial photography method did require a significant amount of data analysis time beyond that required for the visual count method. The data analysis included the time to georeference the photographs, digitize redd locations, and produce redd density maps. Additional data is necessary to understand how aerial photography counts compare to visual counts at differing escapement levels, and ratios would need to be developed so that future aerial photography counts could be compared to the historical dataset of visual counts. The aerial photography method requires additional time and funding beyond the visual count method, but provides a more accurate and consistent estimate of fall Chinook redds along the Hanford Reach of the Columbia River, especially at high escapement levels. 
HNF-56707

Revision 0

\subsection{References}

Anglin, D.R., Haeseker, S.L., Skalicky, J.J., Schaller, H., Tiffan, K.F., Hatten, J.R., Hoffarth, P., Nugent, J., Benner, D., Yoshinaka, M, 2006, Effects of Hydropower Operations on Spawning Habitat, Rearing Habitat, and Stranding/Entrapment Mortality of Fall Chinook Salmon in the Hanford Reach of the Columbia River, Final Repor, Columbia River Fisheries Program Office, U.S. Fish and Wildlife Service, Vancouver, Washington. Online at: http://www.fws.gov/columbiariver/publications/final hanford report 8-10-2006.pdf

Chapman, D. W., D. E. Weitkamp , T. L. Welsh, M. B. Dell \& T. H. Schadt, 1986, Effects of River Flow on the Distribution of Chinook Salmon Redds, Transactions of the American Fisheries Society, 115:4, 537547. Online at: http://www.tandfonline.com/doi/pdf/10.1577/15488659\%281986\%29115\%3c537\%3aeorfot\%3e2.0.co\%3b2

Comprehensive Environmental Response, Compensation, and Liability Act of 1980, 42 U.S.C. 9601-9675. (P.L. 96-510).

Dauble, D. D., D. G. Watson, 1990, Spawning and Abundance of Fall Chinook Salmon (Oncorhynchus tshawytscha) in the Hanford Reach of the Columbia River, 1948-1988, PNL-7289. Pacific Northwest Laboratory, Richland, Washington. Online at: http://www5.hanford.gov/arpir/?content=findpage\&akey=d196110653

Dauble, D. D. and D. G. Watson, 1997, Status of Fall Chinook Salmon Populations in the Mid-Columbia River, 1948-1992, North American Journal of Fisheries Management, 17:2, 283-300. Online at: http://dx.doi.org/10.1577/1548-8675(1997)017<0283:sofcsp>2.3.co;2

DOE/EIS-0222-F, 1999, Final Hanford Comprehensive Land-Use Plan Environmental Impact Statement, U.S. Department of Energy, Washington, D.C. Online at: http://energy.gov/nepa/downloads/eis0222-final-environmental-impact-statement-0

DOE/RL-2011-119 Rev 0, 2011, Hanford Site Environmental Report for CY2011, U.S. Department of Energy, Richland Operations Office, Richland, Washington. Online at: http://msa.hanford.gov/msa/filedisplay.cfm?fileid=1607\&confirm=true

DOE/RL-96-32 Rev 1, 2013, Hanford Site Biological Resources Management Plan, U.S. Department of Energy, Richland Operations Office, Richland, Washington. Online at: http://www.hanford.gov/files.cfm/doe-rl-96-32-01.pdf

Fulton, L. A., 1968, Spawning areas and abundance of Chinook salmon, Oncorhynchus tshawytscha, in the Columbia River Basin-past and present, U.S. Fish. Wildl. Serv. Spec. Sci. Rep. Fish. 571:26. Online at: http://www.nwfsc.noaa.gov/assets/26/7374 08042010145107 fulton.1968-rev.pdf

Healey, M. C., 1991, The life history of Chinook salmon (Oncorhynchus tshawytscha), In C. Groot and L. Margolis (eds.), Life History of Pacific Salmon, p. 311-393, Univ. B.C. Press, Vancouver, B.C.

Hoffarth, P.A, 2014, 2013 District 4 Fish Management Annual Report, Annual Report to Washington Department of Fish and Wildlife, Region 3 Yakima. 
HNF-56707

Revision 0

HNF-54808, Rev. 0, 2013, Fall Chinook Redd Monitoring Report Calendar Year 2012, P. Wagner, C. Lindsey, and J. J. Nugent, Prepared by Mission Support Alliance for the U.S. Department of Energy, Richland, Washington. Online at: http://www.hanford.gov/files.cfm/hnf-54808 - rev 00 nc.pdf

HNF-53665, Rev. 0, 2012, Steelhead Redd Monitoring Report for Calendar Year 2012, P.G. Wagner, C. T. Lindsey, and J. J. Nugent, Prepared by Mission Support Alliance for the U.S. Department of Energy, Richland, Washington. Online at: http://www.hanford.gov/files.cfm/hnf-53665 - rev 00.pdf

HNF-52190, Rev. 0, 2012, Fall Chinook Redd Monitoring Report Calendar Year 2011, P. Wagner, C. Lindsey, and J. J. Nugent, Prepared by Mission Support Alliance for the U.S. Department of Energy, Richland, Washington. Online at: http://www.hanford.gov/files.cfm/hnf-52190 rev 00\%20public\%20relesed.pdf

Mission Support Alliance (MSA), 2014, Hanford Site Annual Environmental Reports, Prepared by Mission Support Alliance for the U.S. Department of Energy, Richland, Washington. Online at: http://msa.hanford.gov/page.cfm/enviroreports

Myers, J. M., R. G. Kope, G. J. Bryant, D. Teel, L. J. Lierheimer, T.C. Wainwright, W.S. Grant, F.W. Waknitz, K. Neely, S.T. Lindley, and R.S. Waples, 1998, Status Review of Chinook Salmon from Washington, Idaho, Oregon, and California. Online at: http://www.nwr.noaa.gov/publications/status reviews/salmon steelhead/chinook/sr1998chinook1.pdf

National Environmental Policy Act of 1969, 42 U.S.C. 4321, et seq. (P.L. 91-190).

Netboy, A., 1958, Salmon of the Pacific Northwest: Fish vs. Dams, Binfords \& Mort, Portland, Oregon.

Swan, G. A., 1989, Chinook Salmon Spawning Surveys in Deep Waters of a Large, Regulated River, In Regulated Rivers: Research \& Management, Vol. 4 p. 355-370. Online at: http://www.nwfsc.noaa.gov/assets/2/8601 07122012094837 swan.1989.pdf

USACE (U.S. Army Corps of Engineers), 2006, Hanford Reach Fall Chinook Protection Program, Hanford Reach Fall Chinook Protection Program Executed Agreement. Online at: http://www.nwdwc.usace.army.mil/tmt/documents/wmp/2006/draft/app7.pdf

Visser, R., D. D. Dauble, D. R. Geist., 2002, Use of Aerial Photography to Monitor Fall Chinook Salmon Spawning in the Columbia River, Transactions of the American Fisheries Society, 131:6, 1173-1179. Online at: http://dx.doi.org/10.1577/1548-8659(2002)131<1173:uoaptm>2.0.co;2

WCH-380, 2010, Field Summary Report for Remedial Investigation of Hanford Site Releases to the Columbia River, Hanford Site, Washington, L. C. Husltrom and B. L. Tiller, Prepared by Washington Closure Hanford for the U.S. Department of Energy, Richland, Washington. Online at: http://www.washingtonclosure.com/projects/environmental protection/mission completion/pr oject library/ 
HNF-56707

Revision 0

This page intentionally left blank. 